SELÇUK ÜNIVERSITTESI

HUKUK FAKÜLTESI DERGISII

Selçuk Law Review

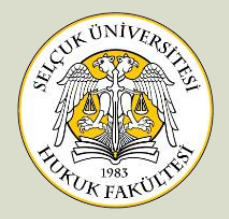

Araştırma Makalesi Research Article

Gönderim | Received: 29.04.2021

Kabul | Accepted: 20.08.2021

doi) $10.15337 /$ suhfd. 929815

\title{
CEZA HUKUKU BOYUTUYLA SİBER ZORBALIK
}

\author{
Dr. Volkan MAVIŞ*
}

\section{Öz}

İletişim teknolojilerindeki gelişmeye paralel şekilde kamuoyunda çevrimiçi güvenliğe ilişkin kaygılar artmıştır. Siber güvenliğe ilişkin en önemli sorunlardan birisi yalnızca okul çocuklarını değil, farklı profilden bireyleri de etkileyen siber zorbalıktır. Siber zorbalığın depresyon, anksiyete ve hatta intihar gibi ağır neticelere yol açtığı belirtilmektedir. Dünya genelindeki şoke edici çeşitli siber zorbalık vakaları, siber zorbalığın cezalandırılıp cezalandırılmaması gerektiğine yönelik tartışmaları ateşlemiştir. Siber zorbalığın cezalandırılması bakımından iki temel yaklaşım önerilmektedir. Doktrindeki bir görüşe göre, siber zorbalığa ilişkin bağımsız bir suç tipinin kabulü gerekmektedir. Aksi görüş̧e göre, mevcut cezai normları modernize ederek uygulamak sorunun çözümünde yeterlidir. $\mathrm{Bu}$ çalışma, anılan iki yaklaşımı irdelemek ve Türk Ceza Kanunu ışığında bir sonuca ulaşmak amacı taşımaktadır.

\section{Anahtar Kelimeler}

Siber Zorbalık • Zorbalık • Bilişim Suçu • Siber Israrlı Takip • Ceza Hukuku

* Dr. Arş. Gör., İnönü Üniversitesi Hukuk Fakültesi, Ceza ve Ceza Muhakemesi Hukuku ABD, Malatya, Türkiye| Research Assistant Inonu University, Faculty of Law, Department of Criminal and Criminal Procedure Law, Malatya, Turkey.

凹volkan.mavis@inonu.edu.tr• ORCiD 0000-0001-9182-3130

Atıf Şekli | Cite As: MAVIŞ Volkan, "Ceza Hukuku Boyutuyla Siber Zorbalık”, SüHFD., C. 29, S. 3, 2021, s. 2455-2500.

İntihal | Plagiarism: Bu makale intihal programında taranmış ve en az iki hakem incelemesinden geçmiştir. I This article has been scanned via a plagiarism software and reviewed by at least two referees. 


\title{
CYBERBULLYING IN THE CONTEXT OF CRIMINAL LAW
}

\begin{abstract}
There is growing public concern about online safety in parallel with the rapid development of telecommunication technologies. One of the most considerable issues regarding cyber safety is cyberbullying which affects not only school children but also people from different backgrounds. It has been stressed that cyberbullying may result in severe consequences such as depression, anxiety and even suicide. Some of the highly disturbing cyberbullying incidents around the world have given rise to discussion whether cyberbullying should be criminalised or not. In terms of criminalising cyberbullying, two main approaches have been proposed. According to an opinion, a new type of cyberbullying crime is necessary to fight cyberbullying. The opponent's idea is that modernising existing criminal law norms is an adequate solution to the problem. This paper aims to review these two arguments and arrive at a conclusion in the light of Turkish Criminal Code.
\end{abstract}

\section{Key Words}

Cyberbullying • Bullying • Cybercrime $\bullet$ Cyberstalking $\bullet$ Criminal Law

\section{GİRIŞ}

Teknolojideki ve buna paralel olarak iletişim tekniklerindeki gelişim, sağladığı faydaların yanında önemli sorunların ortaya çıkmasına da zemin hazırlamıştır. Bu durumun sonucu olarak, hemen her ülkede bilişim alanında karşılaşılan problemleri gidermeye yönelik pek çok düzenleme yapılmıştır. Belirtelim ki teknolojik sıçrama yeni sorunlar doğurmanın yanında var olan sorunların farklı bir format kazanmasına da yol açmıştır. Uzun yıllardır daha ziyade öğrenciler arasındaki bir problem olarak değerlendirilen, yüz yüze (akran) zorbalık da bu farklılı̆̆ın görüldüğü alanlardan birisidir. İletişim olanaklarının gelişimiyle birlikte zorbalık da sanal dünyaya taşınmış ve mağdurun hayatının her alanına işleyebilen bir boyut kazanmıştır. Yine iletişim olanaklarının sınırsız yapısı, zorbalığı yaşıtlar arasındaki bir güç gösteri olmaktan çıkartarak her yaş grubunun tecrübe edebileceği bir noktaya taşımıştır.

Yapılan çeşitli araştırmalar siber zorbalığın ne kadar yaygın olduğunu ve ciddi sonuçlar yaratabileceğini ortaya koymaktadır. Polonya'da 2143 genç (yaklaşık \%94'ü on beş yaşında) üzerinde yapılan bir araştırmaya göre; son bir yıl içerisinde, katılımcıların \%66'sı elektronik ortamda saldırganca davranışlarda bulunmuş, katılımcıların \% 25'i bu eylem- 
leri siber zorbalık oluşturacak şekilde gerçekleştirmiştir. ${ }^{1}$ Türkiye'de yürütülen araştırmalar da siber zorbalığın yaygın bir sorun olduğuna işaret etmektedir. İstanbul'daki farklı ortaöğretim kurumlarından 269 öğrenci üzerinde yapılan bir çalışmaya göre; katılımcıların \% 35,7'sinin siber saldırganlıkta bulunduğu, katılımcıların \% 23,8'sinin ise siber zorbalık mağduru olduğu belirlenmiştir. ${ }^{2}$ Konya' da yapılan bir başka araştırmada, katılımcıların \% 42,4'ü siber zorbalığa maruz kaldığını belirtmiştir. ${ }^{3}$

Her geçen gün büyüyen siber zorbalık sorununa ne şekilde yaklaşılması gerektiğine yönelik görüş birliği yoktur. Kimi ülkelerde tazminat hukukunun çözüm sunmakta başarılı olacağı anlayışı hakim olduğundan, siber zorbalığı cezalandırmaya gerek görülmemiştir. Öte yandan, özellikle Kara Avrupası ülkelerinde siber zorbalığın ceza hukukuna konu edildiği gözlemlenmektedir. Öyle ki Avusturya gibi bazı ülkelerde siber zorbalık bağımsız bir suç tipi olarak düzenlenmiştir.

Çalışmamız, ceza hukuku müdahalesinin gerekip gerekmediğini, olası bir müdahalenin hangi şekilde gerçekleştirilmesinin daha uygun olacağını incelemektedir. Bu bağlamda, çalışma esas olarak iki ana parçadan oluşmaktadır. Öncelikle çalışmanın ilk bölümünde, siber zorbalık kavramı ve unsurları ile siber zorbalığın yaratabileceği olası sorunlara değinilmektedir. Zira kavrama ilişkin temel bilgiler sunulduktan sonra ceza hukuku bakımından değerlendirmelerde bulunmak mümkün olur. İkinci bölümde, siber zorbalığın ceza hukukuyla olan ilişkisi ve mevcut yaklaşımlar incelendikten sonra, bağımsız bir suç tipinin gerekliliği tartışılacaktır.

$1 \quad$ PYZALSKI, Jacek, "From Cyberbullying to Electronic Aggression: Typology of the Phenomenon", Emotional and Behavioural Difficulties, Vol. 17, No. 3-4, 2012, s. 313.

2 ARICAK, Tolga / SIYAHHAN, Sinem / UZUNHASANOGLU, Aysegul / SARIBEYOGLU, Sevda / CIPLAK, Songul / YILMAZ, Nesrin / MEMMEDOV, Cemil, “Cyberbullying Among Turkish Adolescents", CyberPsychology \& Behavior, Vol. 11, Iss. 3, 2008, s. 256.

3 DİLMAÇ, Bülent / AYDOĞAN, Didem, “Parental Attitudes as a Predictor of Cyber Bullying among Primary School Children", International Scholarly and Scientific Research \& Innovation, Vol. 4, Iss. 7, 2010, s. 1669. 


\section{SİBER ZORBALIK}

\section{A. KAVRAM}

Siber zorbalık sorunu ve bunun ceza hukuk bakımından değerlendirilmesi kavramın içeriğinin belirlenmesiyle mümkündür. Bilim insanlarının siber zorbalık gibi görece yeni bir alanda çalışmaya başladıklarında, belirli bir çerçeve oluşturmakta zorlandıkları belirtilmektedir. ${ }^{4}$ Nitekim akademisyenlerin ve araştırmacıların konuyla ilgili olarak, belirli bir kavramda birleştiğini söylemek zordur. İngilizce ve Almanca literatürde elektronik saldırganlık, elektronik zorbalık, ${ }^{5}$ internet zorbalığı, ${ }^{7}$ siber mobbing 8 gibi kavramlar da kullanılmakla birlikte, daha ziyade "siber zorbalık"ın tercih edildiğini söylemek yanlış olmaz.

Türkçe literatüre bakıldığında "siber zorbalık"9 ya da "sanal zorbalık"10 kavramlarının kullanıldığ1 görülür. Anlaşılacağı üzere, cyber keli-

4 KOWALSKI, Robin M. / LIMBER, Susan P. / AGATSTON, Patricia W., Cyberbullying: Bullying in the Digital Age, Wiley-Blackwell, Malden, 2012, s. 58.

5 PYZALSKI, s. 305.

KOWALSKI, Robin M. / LIMBER, Susan P., “Electronic Bullying Among Middle School Students", Journal of Adolescent Health, Vol. 41, 2007, s. 22.

7 WILLIAMS, Kirk R. / GUERRA, Nancy G., "Prevalence and Predictors of Internet Bullying", Journal of Adolescent Health, Vol. 41, 2007, s. 14 vd.

8 AUER-REINSDORFF, Astrid, "Kinderschutz im Internet: Technische Lösungen sowie Informationsangebote an Eltern, Schulen und Kinder", Familie Partnerschaft Recht, Heft: 10, 2012, s. 437.

9 DÜLGER, Murat Volkan, Bilişim Suçları ve İnternet İletişim Hukuku, 8. B., Seçkin Yay., Ankara, 2020, s. 121; POLAT, Oğuz, Kriminoloji ve Kriminalistik Üzerine Notlar, 4. B., Seçkin Yay., Ankara 2018, s. 79; SOYGÜT, M. Buket, “Kadına Yönelik Dijital Şiddet Biçimi Olarak Siber-Stalking", in Kadın Yazıları, Ed. YALÇIN, Türkan, Savaş Yay., Ankara 2020, s. 188; TAŞTEKİN, Ezgi / BAYHAN, Pınar, "Ergenler Arasındaki Siber Zorbalı̆̆ın ve Mağduriyetin İncelenmesi", Online Journal of Technology Addiction and Cyberbullying, C. 5, S. 2, 2018, s. 21 vd.; UŞAKLIOĞLU, Ahmet Yavuz, Dijital Hukuk, 2. B., Seçkin Yay., Ankara 2021, s. 163; EROĞLU, Yüksel / GÜLER, Neşe, “Koşullu Öz-Değer, Riskli İnternet Davranışları ve Siber Zorbalık / Mağduriyet Arasındaki İlişkinin İncelenmesi", Sakarya University Journal of Education, C. 5, S. 3, 2015, s. 118 vd.; RTÜK, Çocukların Yeni Medya Kullanım Alışkanlıkları ve Siber Zorbalık, Değişim Yay., Ankara 2018, s. 161 vd. “Siber Bullying", kavramının da tercih edildiği görülebilir. GÜNŞEN İÇLİ, Tülin, Kriminoloji, 10. B., Seçkin Yay., Ankara 2019, s. 170.

10 GÖLPEK SARI, Fatma / SEFEROĞLU, Süleyman Sadi, “Ortaokul Öğrencilerinin Sanal Zorbalık Farkındalık Durumları ile Sanal Zorbalık Yapma ve Mağdur Olma Durumlarının İncelenmesi", Online Journal of Technology Addiction and Cyberbullying, C. 6, S. 1, 2019, s. 54 vd.; FIRAT, Meryem / AYRAN, Gülsün, “Üniversite 
mesi bazen siber şeklinde dilimize aktarılmakta bazen de Türkçe'ye çevrilerek sanal kullanılmaktadır. Bu konuyla bağlantılı olarak öğretide, siber ya da sanal suç kavramlarının kullanılmasının yetersiz olduğu, işlenen suçlar sanal değil gerçek olduğu ve Türkçe olduğu için "bilişim $s u c ̧ u$ " ifadesinin tercih edilmesi gerektiği savunulmaktadır. ${ }^{11} \mathrm{Bu}$ tespitten hareketle, "bilişim zorbalı̆̆ı" kavramının kullanılması önerilebilir. Ne var ki, bilişim suçu kavramını kullanan yazarlar dahi "siber zorbalık" kalıbını tercih etmektedirler. ${ }^{12}$ Biz de öğretideki baskın görüşe uygun şekilde bu kullanımı benimsiyoruz.

Kavram birliğinin dahi sağlanamadığı düşünüldüğünde siber zorbalığın evrensel bir tanımının yapılamadığını belirtmek şaşırtıcı olmaz. Esasen sorunun teknolojideki ilerlemeye paralel şekilde evrim geçirdiğini ve buna bağlı olarak yapılan tanımların farklılaştığını gözden kaçırmamak gerekir. ${ }^{13}$ Yakın zamanda yalnızca kısa mesajlar göndermeye yarayan cep telefonları yerini akıllı cihazlara bırakmış durumdadır. Milyonlarca insanın kullandığı sosyal ağlara, gelişen bağlantı imkânları sayesinde her yerden her zaman katılmak mümkündür. Dolayısıyla sorunun dinamik bir karakteri olduğunu dikkate almak şarttır. Verilecek tanımların bir yanı itibariyle eksik kalacağı savunulabilir. Konunun önemine binaen, yalnızca bilim insanlarının değil, uluslararası örgütlerin ve hükümetlerin de soruna ilgi gösterdiğini ve çeşitli tanımlar getirdiklerini belirtmek gerekir. Ancak bunların da farklı unsurlardan hareketle oluşturuldukları göze çarpar. Örneğin; daha ziyade gençlerin mağduriyetine yoğunlaşan UNICEF siber zorbalığı, "dijital teknolojilerin kullanılmasıyla gerçekleştirilen zorbalık" olarak tanımlamıştır. ${ }^{14}$ ABD Sağlık

Öğrencileri Arasında Sanal Zorbalık", TAF Preventive Medicine Bulletin, C. 15, S. 4, 2016, s. $322 \mathrm{vd}$.

11 DÜLGER, s. 72. Dar anlamda bilişim suçu ve siber suç kavramlarının aynı anlamda kullanıldığı belirtilmektedir. AKBULUT, Berrin, Bilişim Alanında Suçlar, 2. B., Adalet Yay., Ankara 2017, s. 58. Bilişim suçlarının siber suçları da içeren bir kavram olduğu yönünde bkz. ERDOĞAN, Yavuz, Türk Ceza Kanunu'nda Bilişim Suçları, Legal Yay., İstanbul 2013, s. 45. Sanal ve siber kavramlarının farklı anlamlara geldiği yönünde bkz. TANRIKULU, İbrahim, "Siber Zorbalık ve Kavramsal Konular", in Siber Zorbalık, Ed. TANRIKULU, İbrahim, Anı Yay., Ankara 2020, s. 8.

12 DÜLGER, s. 121.

13 BETTS Lucy R., Cyberbullying: Approaches, Consequences and Interventions, Palgrave Macmillan, Nottingham, 2016, s. 10.

14 UNICEF, "Cyberbullying: What Is It and How to Stop It?", www.unicef.org/endviolence/how-to-stop-cyberbullying, (Erişim tarihi: 18.02.2020). 
ve Sosyal Yardım Bakanlığı ise siber zorbalığı, "cep telefonu, bilgisayar ve tablet gibi dijital cihazlar vasıtasıyla gerçekleştirilen zorbalık" olarak tanımlar. ${ }^{15}$ Türkçe literatürde ise siber zorbalık, "bilgi ve iletişim teknolojileri kullanılarak gerçekleşen zorbalık davranışları",16 "kötü niyetle; sanal araçlar vasıtasıyla başkalarının itibarına zarar verebilen velveya karşı tarafı incitici olan insan onuruyla bağdaşmayan davranışlar"17 olarak tanımlanmıştır. Verilen farklı tanımlardaki unsurları bir araya getirecek olursak, kimi yazarların da vurguladığ1 şekilde"18 siber zorbalık, "üçüncü kişilere zarar vermek amacıyla iletişim teknolojilerinin (elektronik cihazlarm) kasten kötüye kullanımı" şeklinde açıklanabilir.

İlk akla gelen siber zorbalık şekilleri olarak; 1) hakaret, küçük düşürücü ya da tehdit içerikli mesaj veya resimler yaymak, 2) sahte kimlik ya da sosyal ağ hesabı oluşturarak kişileri romantik açıdan kandırmak (catfishing), 3) kasten tartışma yaratmaya yönelik üslup kullanmak (flaming), 4) üçüncü bir kişiymiş gibi hareket etmek (masquerading / impersonation), 5) dedikodu yaymak, 6) rahatsız edici cinsel içerikli resimler ya da videolar göndermek (sexting), 7) mağdurun darp edildiği görüntüleri internette yaymak, 8) kişilerde öfke ve üzüntü yaratmak amaciyla provokatif nitelikli saldırgan paylaşımlarda bulunmak, 9) kişiyi elektronik iletişim araçlarını ısrarla kullanarak rahatsız / tehdit etmek (cyberstalking), 10) daha ziyade küçük düşürücü nitelikteki kişisel bilgileri üçüncü kişilerle paylaşmak (outing) sayılabilir. ${ }^{19}$ Şüphesiz siber zorbalık içerisine dahil edilebilecek eylemlerin çoğaltılması mümkündür. Belirtelim ki saydığımız siber zorbalık şekilleriyle bunları gerçekleştirirken kullanılan yöntemlerin farklı olduğu gözden kaçırılmamalıdır. ${ }^{20}$ Örneğin; siber

StopBullying,

"What

is

Cyberbullying?", www.stopbullying.gov/cyberbullying/what-is-it, (Erişim tarihi: 18.02.2020).

TANRIKULU, s. 9.

UŞAKLIOĞLU, s. 164.

SAVAGE, Matthew W. / TOKUNAGA, Robert S., "Moving toward a Theory: Testing an Integrated Model of Cyberbullying Perpetration, Aggression, Social Skills, and Internet Self-efficacy", Computers in Human Behavior, Vol. 71, 2017, s. 354; BRENNER, Susan W. / REHBERG, Megan, “'Kiddie Crime'? The Utility of Criminal Law in Controlling Cyberbullying", First Amendment Law Review, Vol. 8, 2009, s. 2,3 .

19 KOWALSKI / LIMBER / AGATSTON, s. 62; CHISHOLM, June F., "Review of the Status of Cyberbullying and Cyberbullying Prevention", Journal of Information Systems Education, Vol. 25, Iss. 1, 2014, s. 79. 
zorbalık şekli olan iftira, e-posta, kısa mesaj, sosyal medya gibi farklı metotlarla gerçekleştirilebilir. Benzer şekilde, mağduru küçük düşürücü nitelikteki paylaşımların sosyal medyada yayılması, video paylaşım platformlarına yüklenmesi, yakın çevreye e-posta yoluyla gönderilmesi mümkündür.

Siber zorbalığı tanımlama ve açıklama girişimlerinde sıklıkla yüz yüze (fiziksel, akran) zorbalık olgusuyla paralel yönlere atıfta bulunulmaktadır. İki zorbalık çeşidinin de paylaştı̆̆ı belirli noktalara öğretide vurgu yapılmaktadır. Siber zorbalığın, klasik anlamdaki zorbalığın bir çeşidi sayıldı $\breve{g}^{21}$ düşünüldüğgünde bu çaba yersiz değildir. Pratikte de yüz yüze zorbalık ve siber zorbalık arasında bağlantı bulunduğu belirtilmektedir. ${ }^{22}$ Örneğin; klasik zorbalık mağduru olan çocukların genellikle siber zorbalığa da maruz bırakıldıkları gözlemlenmiştir. ${ }^{23}$

Hem siber hem de yüz yüze zorbalık şekillerinde zorba ve mağdur arasında güç dengesizliği bulunur. ${ }^{24}$ İkinci olarak, her iki zorbalık türünde de eylemin tekrarlanması söz konusudur. ${ }^{25}$ Anılan iki ortak noktanın yanında yazarların farklı çalışmalarda değişik unsurlara yer verdikleri görülür. Örneğin; siber zorbalığın da tıpkı yüz yüze zorbalık gibi

21 ORTEGA, Rosario / ELIPE, Paz / MORA-MERCHAN, Joaquin A. / GENTA, M. Luisa / BRIGHI, Antonella / GUARINI, Annalisa / SMITH, Peter K. / THOMPSON, Fran / TIPPETT, Neil, "The Emotional Impact of Bullying and Cyberbullying on Victims: A European Cross-National Study", Aggressive Behavior, Vol. 38, 2012, s. 342 .

22 DEHUE, Francine / BOLMAN, Catherine / VÖLLINK, Trijntje, "Cyberbullying: Youngsters' Experiences and Parental Perception", CyberPsychology \& Behavior, Vol. 11, Iss. 2, 2008, s. 221.

23 TOKUNAGA, Robert S.: "Following You Home from School: A Critical Review and Synthesis of Research on Cyberbullying Victimization", Computers in Human Behavior, Vol. 26, 2010, s. 279.

24 DOOLEY, Julian J. / PYZALSKI, Jacek / CROSS, Donna, “Cyberbullying Versus Face-to-Face Bullying: A Theoretical and Conceptual Review", Zeitschrift für Psychologie / Journal of Psychology, Vol. 217, Iss. 4, 2009, s. 183 vd.

25 RIZZA, Caroline / PEREIRA, Angela Guimaraes, Social Networks and Cyberbullying Among Teenagers, Publications Office of the EU, Luxembourg, 2013, s. 12. Anılan iki unsurdan ziyade kamuya açılık ve anonimliğin siber zorbalık bakımından daha ağır bastığı savunulmuştur. THOMAS, Hannah J. / CONNOR, Jason P. / SCOTT, James G., "Integrating Traditional Bullying and Cyberbullying: Challenges of Definition and Measurement in Adolescents - a Review", Educational Psychology Review, Vol. 27, Iss. 1, 2015, s. 144. 
saldırgan bir tabiata sahip olduğu savunulmaktadır. ${ }^{26}$ Bazı yazarlarsa üçüncü bir unsur olarak zarar verme kastının varlığına yer vermektedirler. ${ }^{27}$ Bir başka ifadeyle, istemeden üçüncü bir kişiye zarar verecek nitelikteki bir eylemin gerçekleştirilmesi siber zorbalık sayılmamaktadır. Örneğin; mağduru küçük düşürecek nitelikteki bir videoyu yanlışlıkla okul grubuna göndermek siber zorbalık sayılmaz. Öte yandan, siber zorbalığa ilişkin çalışmalar ve teoriler klasik zorbalık üzerine yapılmış eserlere dayansa da iki tür arasında temel farklılıklar bulunur. ${ }^{28}$ Aşağıda mevcut benzer ve farklı yönleri kapsayacak şekilde siber zorbalığın temel özelliklerine ilişkin açıklamalar yapılacaktır.

\section{B. SİBER ZORBALIĞIN TEMEL ÖZELLİKLERİ}

\section{Anonimlik}

Modern iletişim teknolojileri, dileyen kişilerin anonim şekilde iletişime geçmesine olanak sağlar. Sahte e-posta ve sosyal medya hesapları gibi vasıtalar kullanarak mağdura rahatsızlık verilmesi oldukça kolaydır. Esasen pek çok vakada mağdurlar kendilerine zorbalıkta bulunan kişilerin kimliklerini bilmekte ya da tahmin edebilmekte olsalar da anonimlik, yüz yüze zorbalıkta bulunmayan önemli bir özelliktir. ${ }^{29}$ Siber zorbalıkta bulunanlar sıklıkla kimliklerini gizlemeyi ya da değiştirmeyi tercih ederler. Gerçekten de mağdur, zorbalıkta bulunanın bir kişi veya grup mu olduğunu, kadın mı erkek mi olduğunu, yabancı mı yoksa tanıdık mı olduğunu bilemez.

Getirdiği çeşitli kolaylıklar hem faili daha planlı ve dikkatli hareket etme külfetinden kurtarır hem de yakalanma ihtimalini azaltır. ${ }^{30}$ Kaldı ki, kimliğin belirsiz olması zorbanın sosyal kınamayla karşılaşması olanağını da ortadan kaldırır. Toplumsal bir yaptırımın muhatabı olmayacak saldırgan, eylemlerini ahlaki ikilemde kalmadan rahatlıkla gerçekleştirir. Bunun yanında, zorbalıkta bulunanın kimliğinin bilinmemesi mağduru saldırıya daha açı bir pozisyona iter, üzerindeki hakimiyetin daha şiddetli olmasını sağlar. Yine saldırganın kimliğinin bi-

26 KOWALSKI / LIMBER / AGATSTON, s. 82.

27 DOOLEY / PYZALSKI / CROSS, s. 183; TANRIKULU, s. 9. Her iki unsura da vurgu yapan yazarlar vardır. Bkz. FRANCO, Liat / GHANAYIM, Khalid, "The Criminalization of Cyberbullying among Children and Youth", Santa Clara Journal of International Law, Vol. 17, Iss. 2, 2019, s. 7.

28 TOKUNAGA, s. 279.

29 RIZZA / PEREIRA, s. 12.

30 TOKUNAGA, s. 279. 
linmemesi mağduru daha fazla korkuya iteceği gibi kafa karışıklığı da yaratır. ${ }^{31}$ Mağdur saldırının nereden geldiğini bilemediğinden tepki gösteremez ve sebep olduğu zararlı sonuçlara tanık olmayan zorba eylemlerine devam eder. ${ }^{32}$

\section{Erişilebilirlik}

Siber zorbalığın ana unsurlarından bir tanesi mağdura erişimin çok daha kolay olmasıdır. Siber zorbalık halinde, yüz yüze zorbalıktan farklı olarak failin mağdura erişebilme imkânı daha fazladır. ${ }^{33}$ Geleneksel zorbalık daha ziyade okulda, okul servisinde ya da eve dönüş yolunda gerçekleşmekle birlikte, siber zorbalık mağduru eve kadar takip eder. Zira yüz yüze zorbalıkta mağduriyeti yaratan fiziksel etkileşim burada gerekli değildir. ${ }^{34}$ Dolayısıyla mağdurun kendisini güvende hissetmesi gereken ev ortamı dahi gerekli korumayı sağlamaz.

Siber zorbalığa uğrayan kişilerin elektronik cihazlarını kapatması gibi yöntemler erişilebilirliği engellemek bakımından önerilebilir. Ancak, beklemede kalan mesajlar, e-postalar ortadan kalkmaz, cihazların açılmasıyla birlikte yine kullanıcıya ulaşır. Kaldı ki, internette gerçekleşen bu zorbalık şeklinin yoğun kamusallık özelliği de gözden kaçırılmamalıdır. Mağdur faille muhatap olmasa, görmezden gelse dahi kendisiyle ilgili resimlerin, videoların paylaşılmaya devam etmesi mümkündür. Sonuç olarak, iletişim teknolojilerindeki ilerleme mağdurun kendisine ulaşılmasını engelleme imkanını büyük ölçüde ortadan kaldırmış durumdadır.

\section{Güç Dengesizliği}

Zorbalığın temel özelliklerinden bir tanesi zorba ve mağdur arasındaki güç dengesizliğidir. Mağduru güç dengesizliğiyle savunmasız kılması zorbalığı diğer saldırgan fiillerden ayırır. ${ }^{35}$ Özellikle akran zorbalığında fiziksel üstünlüğe dayanan net bir dengesizlik mevcuttur.

\footnotetext{
$31 \quad$ BETTS, s. 44.

32 DEHUE / BOLMAN / VÖLLINK, s. 217.

33 KOWALSKI / LIMBER / AGATSTON, s. 83; BRUN, Marcel, “Cyberbullying - aus strafrechtlicher Sicht", Recht, Heft: 2, 2016, s. 102.

34 PATCHIN, Justin W. / HINDUJA, Sameer, "Bullies Move Beyond the Schoolyard: A Preliminary Look at Cyberbullying", Youth Violence and Juvenile Justice, Vol. 4, Iss. 2, 2006, s. 150.

35 ORTEGA / ELIPE / MORA-MERCHAN / GENTA / BRIGHI / GUARINI / SMITH / THOMPSON / TIPPETT, s. 354.
} 
Okulda ya da oyun parkında iri ve güçlü çocuğun küçüğe yaptığ1 eziyet ilk akla gelen örnektir. Siber zorbalık halinde mevcut olan güçlerin orantısızlığı ise daha önce vurguladığımız anonimlik niteliğinden kaynaklanır. ${ }^{36}$ Anonim kimliğinin arkasına sığınan zorbanın yüz yüze olabileceğinden daha saldırgan bir tavra girmesi kuvvetle muhtemeldir.

Yine siber zorbalıkta, zorbanın mağdur üzerindeki fiziksel hakimiyeti yerine teknolojik olanaklara erişim imkânı da gücü belirleyebilir. ${ }^{37}$ Teknolojiye ilişkin bilginin artmasına paralel olarak, zorbalık şekillerinin çoğalması ve verilen zararın artması söz konusu olur. Normal şartlarda zorbalıkta bulunma gücü olmayanlar dahi sahip oldukları bilgi ve olanaklarla kolay şekilde siber zorbalık yapabilirler. ${ }^{38}$ Oldukça basit yöntemlerle de (mesaj göndermek) güç dengesizliğinin yaratılması mümkündür.

Failin sahip olduğu imkânların yanında mağdurun saldırıdan kurtulma olanaksızlığı da önemli bir faktördür. ${ }^{39}$ Yüz yüze zorbalıktan farklı olarak saldırının ne zaman gelebileceğini öngörmek ve ona göre tedbir almak mümkün değildir; mağdur evindeyken dahi zorbalığa uğrayabilir. Dolayısıyla mağdurun süreci kontrol etme iktidarına sahip olmaması kendisini daha güçsüz hissetmesine ve neticede güç dengesizliği oluşmasina yol açar.

\section{Tekrar Etme}

Klasik anlamdaki zorbalığı diğer türlü saldırılardan ayıran temel noktalardan bir tanesi eylemin tekrar tekrar gerçekleştirilmesidir. ${ }^{40}$ Yüz yüze zorbalıktaki bu ana unsur, siber zorbalık için de genellikle olmazsa olmaz kabul edilir. ${ }^{41}$ Eylemin tekrarlanıyor olması siber zorbalığı diğer siber saldırganlık şekillerinden ayırır. Ne var ki, hangi hallerde bu şartın sağlanmış olacağına ilişkin öğretide farklı görüşler mevcuttur. Esas olanın eylemin birden fazla gerçekleştirilmesi mi, yoksa etkisinin devamlı-

36 MARK, Lauren / RATLIFFE, Katherine T., "Cyber Worlds: New Playgrounds for Bullying", Computers in School, Vol. 28, Iss. 2, 2011, s. 94.

37 CHISHOLM, s. 81; POLAT, s. 80.

38 VANDEBOSCH, Heidi / CLEEMPUT, Katrien Van, “Defining Cyberbullying: A Qualitative Research into the Perceptions of Youngsters", CyberPsychology \& Behavior, Vol. 11, Iss. 4, 2008, s. 502.

39 DOOLEY / PYZALSKI / CROSS, s. 184.

40 WILLIAMS / GUERRA, s. 514.

41 BETTS, s. 38; PYZALSKI, s. 313. Tek bir kez gerçekleşen eylemlerin de siber zorbalık sayılabileceği yönünde bkz. VANDEBOSCH / CLEEMPUT, s. 501. 
lık göstermesi mi olduğu soruları akla gelebilir. Eylemin sayısına bağlı kalmaktan ziyade gerçekleşme şeklini dikkate almakta fayda vardır. Sürekli olarak mağdura alay içerikli mesajlar göndermek şüphesiz siber zorbalık sayılmalıdır. Bununla birlikte, tek bir kez gerçekleştirilen eylem mağdurun defalarca zarar görmesine yol açabilir. Örneğin; mağduru küçük düşürücü bir fotoğrafın, videonun kamuya açık şekilde paylaşılması, söz konusu fotoğrafa her erişim sağlandığında mağduriyetin tekrarlanmasına yol açar ve siber zorbalık oluşturur. O halde, eylemin tekrarlanması daha ziyade kamuya açık olmayan eylemlerin siber zorbalık sayılması bakımindan belirleyicidir. ${ }^{42}$ Tek bir eylem dahi siber zorbalık oluşturabileceğine göre davranışın tekrarlanmasını mutlak bir unsur olarak değerlendirmemek gerekir. Tekrar etmeyi siber zorbalığı tanımlayan değil eylemin ağırlığını gösteren bir öge saymak daha isabetli olur. ${ }^{43}$

\section{Denetimsizlik}

Gerçek hayattan farklı olarak sanal dünyada saldırgan davranışların denetlenebilirliği daha düşüktür. Çoğu örnekte zorbanın ailesi ya sürdürülen saldırgan davranışın farkında değildir ya da bu durumu umursamaz. Özellikle günümüz gençlerinin teknolojik cihazlar konusunda ebeveynlerinden daha bilgili oldukları düşünüldüğünde, yakalanma korkusu yaşamadan eylemlerine devam etmeleri olasılığı yüksektir. ${ }^{44}$ Ayrıca, mevcut denetimsizlik mağdurun tutumundan da kaynaklanabilir. Mağdur edildiğini öğrenen ailesinin bilgisayarını, cep telefonunu alacağından korkan gençler, siber zorbalığg saklama yoluna gidebilmektedirler. ${ }^{45}$ Araştırmalar da ergen bireylerin ailelerine ve öğretmenlerine başvurmak yerine mağduriyetlerini arkadaşlarına anlatmayı tercih ettiklerini ortaya koymaktadır. ${ }^{46}$

Siber zorbalığı denetleme güçlüğü yalnızca gençler arasında gerçekleşen vakalar bakımından geçerli değildir. Modern iletişim yöntemleri yetişkinler arasındaki zorbalık eylemlerinin de denetimini zorlaştı-

\footnotetext{
42 THOMAS / CONNOR / SCOTT, s. 143.

43 RODKIN, Philip C. / FISCHER, Karla, "Cyberbullying from Psychological and Legal Perspectives", Missouri Law Review, Vol. 77, Iss. 3, 2012, s. 625.

$44 \quad$ PATCHIN / HINDUJA, s. 154.

45 MARK/RATLIFFE, s. 94.

46 ARICAK / SIYAHHAN / UZUNHASANOGLU / SARIBEYOGLU / CIPLAK / YILMAZ / MEMMEDOV, s. 258.
} 
rır. Özellikle çoğu durumda zorbalık, saldırgan ve mağdur arasında kamuya kapalı şekilde gerçekleşir. Kamuya açık alanda gerçekleşen zorbalığın da takibi her zaman mümkün olmaz. Twitter, Facebook gibi sosyal medya şirketleri saldırgan dil kullanımı halinde yaptırımlar uygulasalar da böyle bir denetim şekline her mecrada denk gelmek mümkün değildir.

\section{6. Üçüncü Kişilerin Katılımı}

Fiziksel zorbalık daha ziyade kısıtlı sayıdaki kişi veya kişilerin huzurunda gerçekleştirilir. Potansiyel tanıkların zorba ve mağdurla aynı mekânda bulunması birinci elden şahit olmanın gereğidir. Buna bağlı olarak, eylemin hem zorba hem de mağdur üzerindeki yansıması görece daha sınırlı şekilde kendisini gösterir; zira mağdurun içine düşürüldüğü küçültücü durumu gören kişi azdır. Halbuki, sanal dünyanın niteliği gereği belirsiz sayıda insanın sanal zorbalığa şahit olması söz konusudur. Öyle ki ne saldırganı ne de mağduru tanıyan kişiler dahi gerçekleştirilen zorbalıktan haberdar olmaktadır. ${ }^{47}$ Gelişen teknolojiyle birlikte aynı zaman ve mekânda bulunma gerekliliği ortadan kalkmıştır. ${ }^{48}$ Dolayısıyla mağdurun yaşadığı utandırıcı deneyime günler sonra dahi tanıklık etmek mümkündür. Elektronik ortamda kayıt altında bulunan bu verilere kolaylıkla erişimin mümkün olduğunu da göz önünde bulundurunca, siber zorbalığın daha yoğun etkisi anlaşılabilir. ${ }^{49}$ Her ne kadar önemi günden güne artan unutulma hakk1 $1^{50}$ bağlamında verilerin sildirilmesi ya da bu verilere erişimin engellenmesi akla gelse de pratik zorlukları gözden kaçırmamak gerekir. ${ }^{51}$ Esasen söz konusu verilerin sildi-

47 KYRIACOU, Chris / ZUIN, Antônio, “Cyberbullying of Teachers by Students on Youtube: Challenging the Image of Teacher Authority in the Digital Age", Research Papers in Education, Vol. 31, Iss. 3, 2016, s. 257.

BETTS, s. 39.

49 AUER-REINSDORFF, s. 437.

50 "Unutulma hakkı en öz haliyle, bireyin, ona ilişkin bilginin erişimden kaldırılması talebidir." SÖZÜER, Eren, Unutulma Hakk1, On İki Levha Yay., İstanbul 2017, s. 7.

Türk hukukunda çeşitli kanunlarda yer alan hükümlere dayanarak unutulma hakkından faydalanmak mümkündür. Örneğin; 5651 sayılı İnternet Ortamında Yapılan Yayınların Düzenlenmesi ve Bu Yayınlar Yoluyla İşlenen Suçlarla Mücadele Edilmesi Hakkında Kanun'un 9/1. maddesine göre; “Internet ortamında yapılan yayın içeriği nedeniyle kişilik haklarının ihlal edildiğini iddia eden gerçek ve tüzel kişiler ile kurum ve kuruluşlar, içerik sağlayıcısına, buna ulaşamaması halinde yer să̆layıcısına başvurarak uyarı yöntemi ile içeriğin yayından çıkarılmasını isteyebileceği gibi doğrudan sulh ceza hâkimine bassvurarak içeriğin çıkarılmasını ve/veya erisimin engellenmesini de isteyebilir." Yine, 6698 sayılı Kişisel Verilerin Korunması Kanunu'nun 
rilmesinin talep edilmesi ve bu verilerin silinmesi arasında kayda değer bir süre geçmektedir. ${ }^{52}$ Sanal ortamda video, fotoğraf gibi verilere çok kısa süre içerisinde dahi geniş kitlelerin erişmesi mümkündür.

Yüz yüze zorbalıkta çoğunlukla üçüncü kişilerin olaya müdahil olarak mağdurun yanında durmadıkları görülür. Tanıkların hareketsiz kalması saldırgana eylemine devam etmesi bakımından üstü kapalı bir destek sunar. Öte yandan, saldırının üçüncü kişiler önünde meydana gelmesi mağdurun aşağılanmasını artırır. Siber zorbalık halinde söz konusu etkilerin daha şiddetli şekilde ortaya çıkacağı muhakkaktır. Tüm bunların yanında, siber zorbalığa şahit olan kişilerin mağdura yardım etmek bir yana saldırgana eşlik etmesinin kuvvetle muhtemel olduğuna vurgu yapılmaktadır. ${ }^{53}$ Yüz yüze zorbalıktan farklı olarak, fiziksel güç ve cesaret mağdura saldırırken bulunması gereken nitelikler değildir. Sanal dünyanın bu gücünü gören üçüncü kişilerin ve tanıkların saldırganı örnek alarak mağdura yönelmeleri söz konusu olabilir.

\section{SİBER ZORBALIK ÇEŞITLERINIIN SINIFLANDIRILMASI}

Siber zorbalık eylemlerini farklı kıstaslardan hareketle gruplara ayırarak incelemek mümkündür. Kimi yazarlar özellikle okul ortamında gerçekleştirilen siber zorbalık vakalarını gruplandırmaktadırlar. Örneğin; saldırının yöneldiği kişiye (okul personeli, ünlüler) veya saldırıyı gerçekleştirenin (öğrenci, yetişkin) kimliğine göre ayrımlara gidilebilir. Gerek geleneksel zorbalığa gerekse siber zorbalığa ilişkin verdiğimiz örnek ve açılamalar daha ziyade öğrenciler arasında gerçekleşen vakalara değinmektedir. Ne var ki böyle bir zorunluluk bulunmaz ve siber zorbalığın öğrenci (genç) veya öğretmen (yetişkin) tarafından yine öğrenci veya öğretmene karşı gerçekleştirilmesi olasıdır. ${ }^{54}$ Esasen zorbalığı

11(e) maddesine göre ilgili, veri sorumlusundan "7 nci maddede öngörülen şartlar çerçevesinde kişisel verilerin silinmesini veya yok edilmesini isteme, hakkına sahiptir."

52 BETTS, s. 41.

53 KOWALSKI / LIMBER / AGATSTON, s. 85.

54 BRENNER / REHBERG, s. 5 vd.; LANGOS, Colette, Cyberbullying, Associated Harm and the Criminal Law, University of South Australia 2013 (Yayımlanmamış doktora tezi), s. 68, 69.

Nitekim Yargıtay'ın şikâyet yokluğu nedeniyle düşme kararı verilmesi gerektiğini belirttiği örnek bir olay şu şekildedir:

"Sanık hakkında 13.05.2012 tarihinde düzenlenen iddianemeye ve dosya kapsamına göre, ilköğretim okulunda sını öğretmeni olarak görev yapan saniğın, 2008-2009 eğitim öğretim yılında, sorumluluğundaki ikinci sınıf öğrencisi mağdur ...'i yazı tahtasının önüne alarak, 
öğrenciler birbirlerine karşı gerçekleştirseler de öğretmenlerin de mağdur edildikleri görülebilir. ${ }^{55}$ Öyle ki öğretmenlerin birbirlerini siber zorbalığa maruz bırakmaları dahi söz konusu olabilir. Nitekim öğretide cinsiyet, yaş, etnik köken, sınıf fark etmeksizin herkesin siber zorbalık mağduru olabileceği belirtilmektedir. ${ }^{56}$

Öğrencilerin kendi aralarında kullandıkları zorbalık teknikleri benzer şekilde öğretmenlere de yönelebilmektedir. ${ }^{57}$ Öğretmen adına sahte sosyal medya hesabı açarak küçük düşürücü paylaşımlarda bulunmak, öğretmenin e-posta adresini çalarak haberleşme içeriklerini ifşa etmek gibi yöntemler buna örnektir. Siber zorbalığın anonimlik özelliği öğrencilerin rahatlıkla olumsuz yorumlarda bulunmasına zemin hazırlamaktadır. Nitekim normal şartlarda sınıftaki otorite sembolü olan öğretmenlerin bu imajı artık kolaylıkla bozulabilmektedir. ${ }^{58}$ Dolayısıyla öğrenci ve öğretmen arasındaki güç ilişkisinin tersine döndüğü gözlemlenebilir. Esasen öğretmenlerin otoriteye sahip olduğuna ilişkin genel kanaat olası mağduriyetlerinin görmezden gelinmesine de kapı aralar. ${ }^{59}$

Siber zorbalık kamusal ya da özel alanda gerçekleştirilmesine göre de iki grup altında incelenebilir. ${ }^{60}$ Zorbalar genellikle, mağdurda daha fazla etki yarattığı için kamusal nitelikteki siber zorbalık şekillerine yönelmektedirler. Sosyal medyada yapılan paylaşımlar, internet sayfasına yazılan yorumlar bu tür saldırılara örnektir. Belirtmek gerekir ki özel alanda gerçekleştirilen siber zorbalığın kamusal alana taşınması da söz konusu olabilir. Zorbanın mağdura attığı küçük düşürücü mesajları, e-

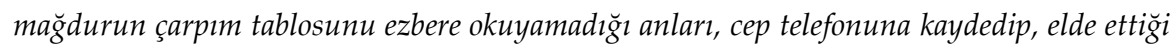
videoyu, mă̆gur ve ailesinin rızası dişında, kendisine ait facebook hesabında yayımlamak suretiyle TCK'nın 134/2. maddesinde düzenlenen özel hayatın gizliliğini ihlal suçunu işlediği iddiasına konu olayda..." Yar. 12. CD., 2014/2926 E., 2014/19496 K., 13.10.2014.

55 Neticede aynı yönde bkz. DÜLGER, s. 121.

56 ARICAK / SIYAHHAN / UZUNHASANOGLU / SARIBEYOGLU / CIPLAK / YILMAZ / MEMMEDOV, s. 254. Ne var ki zorbalık belirli gruptan kişilere karşı daha sık gerçekleştirilmektedir. Eşcinseller, engelliler, kadınlar ve azınlıklar buna örnek olarak gösterilebilir. SABIA, Joseph J. / BASS, Brittany, “Do Anti-Bullying Laws Work? New Evidence on School Safety and Youth Violence", Journal of Population Economics, Vol. 30, 2017, s. 474.

57 VOGL-BAUER, Sally, "When Disgruntled Students Go to Extremes: The Cyberbullying of Instructors", Communication Education, Vol. 63, Iss. 4, 2014, s. 432.

$58 \quad$ KYRIACOU / ZUIN, s. 258.

59 VOGL-BAUER, s. 431.

60 BRENNER / REHBERG, s. 13. 
postaları yayınlaması veya çevresindeki kişilere göndermesi halinde saldırının niteliği değişmiş olur.

Saldırgan ve mağdur arasında birebir gerçekleşen özel nitelikteki siber zorbalık da bir diğer gruptur. Şüphe yok ki küçük düşürücü tutum diğer insanlara yansımadığı için mağduriyetin daha dar kapsamlı olaca$\breve{g}_{1}$ iddia edilebilir. Öte yandan, özel alanda gerçekleşen siber zorbalık fiillerinin de ağır neticelere sebep olması ihtimal dahilindedir.

Ceza hukuku literatüründe siber zorbalığa ilişkin sınıflandırma yapılmamakla birlikte, bu iki tür siber zorbalığın yansımaları ceza hukukunda görülebilir. Örneğin; siber zorbalığın sövmek suretiyle gerçekleştirilmesi söz konusu olabilir ki hakaret suçu yalnızca mağdura ulaşacak şekilde ya da alenen işlenebilir.

Son olarak, öğretide sözlü ve psikolojik siber zorbalık ayrımı yapılmıştır. ${ }^{61}$ Sosyal ağlar, chat odaları gibi kanallarda kişilere sözlü tacizde bulunulması, hakaret edilmesi gibi hallerde siber zorbalık sözlü bir nitelik gösterir. Mağdur hakkında internet üzerinden dedikodu ve yalanlar yaymak, Facebook gibi sosyal ağlardan dişlamak, küçük düşürücü video ve görselleri Youtube gibi platformlarda paylaşmak psikolojik siber zorbalığa örnek olarak sayılmaktadır.

\section{SİBER ZORBALIĞIN ETKİLERİ}

Esasen fiziksel bir etkileşim içermeyen, yalnızca elektronik vasıtalarla yaratılan siber zorbalığın sonuçları da son derece ağır olabilir. Bu tür zorbalık eylemlerinin özellikle psikolojik problemler yaratmasının daha olası olduğu vurgulanmaktadır. Siber zorbalığa maruz kalanların ruh sağlıklarının zarar gördüğü belirtilmektedir. ${ }^{62}$ Mağdurlarda tipik olarak tükenmişlik, öfke, keder gibi tepkiler ortaya çıkar. Bu bağlamda depresyon, anksiyete, konsantrasyon eksikliği ve intihara eğilim gibi klinik semptomların gözlenmesi olasıdır. ${ }^{63}$ Nitekim yapılan araştırmalarda siber zorbalığın depresyonla ve bununla bağlantılı olarak intiharla

61 KATZER, Catarina, Cybermobbing - Wenn das Internet zur Waffe wird, SpringerVerlag, Berlin, 2014, s. 62.

62 BETTS, s. 83. Aynı yöndeki çeşitli veriler için bkz. NIXON, Charisse L., "Current Perspectives: The Impact of Cyberbullying on Adolescent Health", Adolescent Health, Medicine and Therapeutics, Vol. 5, 2014, s. 144, 145.

63 SCHENK, Allison M. / FREMOUW, William J., "Prevalence, Psychological Impact, and Coping of Cyberbully Victims Among College Students", Journal of School Violence, Vol. 11, 2012, s. 25; BARUTÇU YILDIRIM, Funda, “Siber Zorbalığın Sonuçları”, in Siber Zorbalık, Ed. TANRIKULU, İbrahim, Anı Yay., Ankara 2020, s. 213. 
bağlantısı olduğu savunulmuştur. ${ }^{64}$ Örneğin; Vancouver'da yaşayan yedinci sınıf öğrencisi Amanda Todd'un cinsel içerikli pozları internette tanıştığı kişi tarafından yayınlanmış, bunun üzerine öğrenci intihar teşebbüsünde bulunmuştur. İntihar girişiminin başarısız olması, mağdurun Facebook üzerinden tekrar alay konusu olmasına neden olmuştur. Yaşadığ1 psikolojik sorunları Youtube'a yüklediği bir video ile anlatan Amanda, yaklaşık bir ay sonra kendisini asarak intihar etmiştir. Nitekim infial yaratan bu olayın ardından Kanada'da, özel hayata ilişkin fotoğrafların ilgilinin rızası olmaksızın yayılması suç olarak düzenlenmiştir. ${ }^{65}$

Psikolojik etkilerinin yanında siber zorbalık kaynaklı harici sonuçlar da ortaya çıabilir. Ruhsal sorunlarda olduğu kadar yeterli veri bulunmamakla birlikte, bir dizi harici sorunların da baş gösterebileceği vurgulanmıştır. ${ }^{66}$ Örneğin; siber zorbalık mağduru çocukların alkol ve uyuşturucu kullanımına yönelmeleri, okula giderken silah taşımaları yaşıtlarına göre daha olasıdır. Yine siber zorbalığa uğrayan çocuklar okulda sorunlar yaşayabilir ve hatta okula gitmek istemeyebilirler. ${ }^{67}$ Belirtelim ki mağduriyet neticesinde gösterilen tepki cinsiyete bağlı olarak da değişkenlik sergileyebilir. Yapılan araştırmalar, siber zorbalığa tepki olarak mağdur erkeklerin alkol ve uyuşturucu kullanımına yöneldiklerini, kadınlarınsa internet ve cep telefonu kullanımını sınırlandırdıklarını ortaya koymaktadır. ${ }^{68}$

\section{E. TÜRKİYE'DEKİ SİBER ZORBALIK ÇALIŞMALARI}

Siber zorbalık sorununun görünürlük kazanmasına paralel olarak Türkiye'de konuya yönelik yapılan çalışmaların sayısında artış görülmektedir. Radyo ve Televizyon Üst Kurulu'nun ortaokul öğrencileri

64 İntihar gibi davranışların çoklu etkenlerden kaynaklandı̆̆ı, siber zorbalığın tek sebep olarak kabul edilmesinin hatalı olacağı yönünde bkz. KOWALSKI / LIMBER / AGATSTON, s. 149.

65 SUMRALL, Tiffany, "Lethal Words: The Harmful Impact of Cyberbullying and the Need for Federal Criminalization", Houston Law Review, Vol. 53, Iss. 5, 2016, s. 1480 .

Kanada Ceza Kanunu'na eklenen 162. madde, bir kişinin özel görsellerini, ilgilisinin onayı olmadığını bilerek ya da onayı olup olmadığına dikkat etmeyerek kasten yayınlayan, dağıtan, ileten, satan, erişime açan ya da ilan eden kişinin beş yıla kadar hapis cezasıyla cezalandırılmasını öngörmektedir.

66 NIXON, s. 146.

67 BETTS, s. 88; BARUTÇU YILDIRIM, s. 217.

68 SCHENK/FREMOUW, s. 33. 
arasında yaptığı araştırmaya göre, çocukları internette en fazla rahatsız eden sorun siber zorbalıktır. ${ }^{69}$ Yine aynı araştırmada, kız öğrencilerin siber zorbalıktan daha fazla rahatsızlık duyduğu belirlenmiştir. Bu bulguya uygun şekilde, bir başka araştırmada, erkek öğrencilerin daha fazla siber zorbalığa başvurduğu tespit edilmiştir..$^{70}$ Dolayısıyla siber zorbalıktan daha fazla rahatsız olan kız öğrencilerin, siber zorbalığa başvurmaktan kaçındıkları söylenebilir.

Siber zorbalığın denetlenebilirliği sorununda bahsedildiği üzere, mağdurlar genellikle ailelerine, öğretmenlerine ya da resmi makamlara başvurma yoluna gitmemektedirler. Araştırmalar, bu tespitin Türkiye özelinde de geçerli olduğuna işaret etmektedir. Siber zorbalık mağduru çocukların yaklaşık \% 42'si durumu aileleriyle paylaşmaktadırlar. Yaklaşık dört çocuktan birisi ise yaşadığı mağduriyeti kimseye anlatmamaktadır. ${ }^{71}$ Belirtelim ki, cinsiyet farklılığının burada da önemli bir faktör olduğu tespit edilmiştir. Erkek mağdurlar kızlara nazaran, yaşadıklarını paylaşmakta daha isteksizdirler. ${ }^{72}$

Siber zorbaların bu tür eylemlere yönelmelerindeki etkenlere yönelik çalışmalar da dikkat çekmektedir. Aile ilişkilerinin siber zorbalık ve siber mağduriyetin ortaya çıkması bakımından önemli olduğu vurgulanmaktadır. Ailelerin olumsuz davranışları ve siber zorbalık arasında doğrudan ilişki mevcuttur. Baskıcı ve otoriter ebeveynliğin siber zorbalığa yönelmede önemli bir faktör olduğu savunulmuştur. Bu duruma çözüm olarak anne ve babaların, çocuklarını olduğu gibi kabullendikleri daha demokratik bir tutum benimsemeleri önerilmektedir. ${ }^{73}$ Yine anne ve babaların okuldaki eğitmenlerle ortaklaşa hareket etmesinin önemine vurgu yapılmaktadır. Ayrıca siber zorbalığı önlemek için okullarda önleyici danışmanlık servislerinin devreye sokulması savunulmuştur.

Siber zorbalığa yönelmede başka sebeplerin de önemli etkilerinin olabileceği tespit edilmiştir. Üniversite öğrencileri üzerinde yapılan bir araştırmaya göre, kişinin karakter yapısı siber zorbalığa başvurmasında

\footnotetext{
69 RTÜK, s. 163.

70 FIRAT / AYRAN, s. 328. Kız öğrencilerin siber zorbalık farkındalıklarının daha yüksek olduğu belirtilmektedir. GÖLPEK SARI / SEFEROĞLU, s. 72.

$71 \quad$ RTÜK, s. 168.

72 RTÜK, s 169.

73 DİLMAÇ / AYDOĞAN, s. 1670.
} 
ya da mağdur olmasında rol oynayabilir. ${ }^{74}$ Rekabetçi karaktere sahip bireylerin, rekabeti sanal dünyaya taşıyarak siber zorbalığa yönelmeleri ya da mağdur edilmeleri olası görülmektedir. Yine, çevrenin onayını alma isteğiyle sanal zorbalık arasında doğrudan ilişki bulunmaktadır. ${ }^{75}$ Özellikle de akranlarca kabul edilmenin önemli olduğu ergenlik döneminde bu durum daha net görülür. Üniversite öğrencileri bağımsız davranabilme kabiliyetine sahip olduklarından, onay alma amacıyla siber zorbalığa yönelme ihtimali de zayıflamaktadır.

\section{SİBER ZORBALIK VE CEZA HUKUKU}

\section{A. GENEL OLARAK}

Siber zorbalığın ceza hukukunun konusunu oluşturmasının yerindeliği uzun süredir tartışmalıdır. İleride ayrıntılı olarak irdelemek üzere bu konuyu bir kenara koyarsak, halihazırda Avusturya, Yeni Zelanda gibi ülkelerde kanun koyucuların ceza hukuku korumasına başvurmaya başladıkları gözlemlenir. Esasen bu düzenlemeleri hayata geçirirken iki temel yaklaşımın benimsediği vurgulanmaktadır. ${ }^{76}$ Kimi ülkelerde kanun koyucular siber zorbalığı (farklı kavramlarla ifade edilse de) ayrı bir suç tipi olarak düzenleme yoluna gitmişlerdir. Örneğin; Avusturya Ceza Kanunu'nun 107c. maddesiyle telekomünikasyon ve bilgisayar sistemlerini kullanarak devamlı tacizde bulunmak suç olarak düzenlenmiştir. İkinci bir yol olarak, bazı ülkelerde halihazırda yürürlükte bulunan 1srarlı takip, hakaret gibi suç tiplerinin siber zorbalığı da göz önünde bulundurarak yeniden formüle edilmesi dikkat çeker. Almanya'da özel hayatın gizli alanını ihlal suçu siber zorbalığı gözeterek güncellenmiştir.

\section{B. BAĞIMSIZ BİR SUÇ TIPI OLARAK SİBER ZORBALIK}

Bazı devletler çevrimiçi şiddeti ayrı bir suç tipi olarak düzenleme yolunu tercih etmiştir. İlk akla gelen örnek olarak, 2016 yılında Avusturya Ceza Kanunu'nda yapılan düzenleme anılabilir. Avusturya'da böyle bir düzenlemeye gidilmesi, ülkenin Avrupa Birliği üyeleri içerisinde en yüksek siber zorbalık oranına sahip olmasının sonucudur. Nitekim kanun koyucu hakaret, cinsel taciz gibi mevcut suç tiplerinin bu

74 EROĞLU / GÜLER, s. 125.

75 EROĞLU / GÜLER, s. 125.

76 LIDSKY, Lyrissa / GARCIA, Andrea Pinzon, "How Not to Criminalize Cyberbullying", Missouri Law Review, Vol. 77, Iss. 3, 2012, s. 700; BOSTANCI BOZBAYINDIR, Gülşah, "Cyberbullying and Criminal Law", İstanbul Hukuk Mecmuası, S. 77, C. 1, 2019, s. 435; FRANCO / GHANAYIM, s. 21. 
tür zorbalık eylemlerini önlemede yeterli olmadığını görmüş ve yeni bir düzenleme yapılmasını sosyal bakımdan gerekli saymıştır. ${ }^{77}$

Avusturya Ceza Kanunu'nun 107c. maddesinde ${ }^{78}$ telekomünikasyon ya da bilgisayar sistemleri vasitasiyla israrlı tacizde bulunulması suç olarak düzenlemiştir. Buna göre, telekomünikasyon veya bilgisayar sistemlerini kullanarak uzun süreliğine bir kişinin saygınlığına topluluk önünde zarar veren ya da bir kişinin hayatının özel alanına ilişkin bilgi ve resimleri rıza olmaksızın çok sayıda insana ifşa edenler bir yıla kadar hapis veya 720 güne kadar para cezasıyla cezalandırılır. Kanun koyucu, siber zorbalık eylemlerinin mağdurları intihara kadar sürükleyebileceğini de göz önünde bulundurarak neticesi sebebiyle ağırlaşmış hal de düzenlemiştir. Maddenin ikinci fıkrasında, mağdurun intihar etmesi ya da intihara teşebbüs neticesinde yaralanması durumunda failin üç yıla kadar hapis cezasıyla cezalandırılacağ

2015 yılında Yeni Zelanda'da dijital yolla verilen zararlara yönelik özel bir yasa (Harmful Digital Communications Act) kabul edilmiştir. Söz konusu Kanun'un 22. maddesinde ${ }^{79}$ bir kişiye elektronik haberleşme

77 FRANCO / GHANAYIM, s. 22.

78 Telekomünikasyon veya Bilgisayar Sistemi Aracılığıla Devamlı Rahatsız Etme

"1) Bir telekomünikasyon ya da bilgisayar sistemi kullanmak suretiyle bir kişinin yaşam şekline devaml şekilde uzun süreli müdahalede bulunarak;

1. çok sayıda kişinin görebileceğ $i$ şekilde hakaret eden veya

2. kişisel alana ilişkin hususları veya görselleri rızaya aykırı olarak çok sayıda kişiye ifşa eden

kişi bir yıla kadar hapis veya 720 güne kadar adli para cezasıyla cezalandırılır.

"2) Birinci fikradaki eylemin mağdurun intihar etmesine ya da intihara teşebbüsüne sebep olması halinde üç yıla kadar hapis cezasına hükmedilir."

79 Dijital İleti Göndererek Zarar Vermek

"1) Ĕ̆ger bir kişi;

a. mă̆dura zarar verme kastıyla dijital ileti gönderir ve

b. gönderilen ileti mağdurun yerindeki makul bir üçüncü kişiye zarar vermeye elverişliyse ve

c. ileti mağdura zarar vermişse suç oluşur."

2) Bir iletinin zarar vermeye elverişliliğini değerlendirirken mahkeme bağlantılı gördüğ̈̈̈,

a. kullanılan dilin ă̆ırlı̆̆ı,

b. mağdurun yaşı ve kişiliğgi,

c. dijital iletinin anonim olup olmadığ $l$,

d.dijital iletinin tekrarlanıp tekrarlanmadiğı,

e. dijital iletinin yayılma genişliği,

f. dijital iletinin doğru veya yanlış olması,

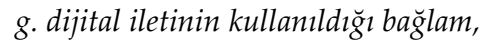


yoluyla zarar verilmesi bağımsız bir suç tipi olarak düzenlenmiştir. Buna göre, elektronik haberleşme vasıtasıyla, makul üçüncü bir kişiye zarar verecek nitelikteki iletilerin kasten gönderilmesi suç oluşturur. Maddenin ikinci fıkrasına göre, eylemin zarar vermeye elverişliliğini değerlendiren mahkeme, kullanılan dilin ağırlığı, mağdurun yaşı ve kişiliği, eylemin anonim şekilde gerçekleştirilip gerçekleştirilmediği, eylemin tekrarlanıp tekrarlanmadığı, iletinin ne kadar yayıldığı, iletinin doğru olup olmadığı, iletinin hangi bağlamda kullanıldığı gibi etkenleri dikkate alır. Kanun koyucu yaptırım olarak, iki yıla kadar hapis veya 50.000 dolar adli para cezası öngörmüştür.

Amerika Birleşik Devletleri'nde (ABD) siber zorbalığa ilişkin cezai düzenlemeler her eyalette farklılık gösterir. Siber zorbalık kavramı pek çok eyalette mevzuata dahil edilmiş, kimi eyaletlerde ise bağımsız bir suç tipi olarak da düzenlenmiştir. Arkansas eyaletinde ayrı bir suç olarak kaleme alınan siber zorbalık, bir kişiye yoğun, devamlı veya düşmanca şekilde, korkutma, zorlama, sindirme, tehdit, suistimal veya hakaret amaciyla elektronik araçlarla ileti transferi, gönderilmesi ya da paylaşılmasını ifade eder. ${ }^{80}$ Kanun koyucu siber zorbalığ 1 ikinci derece kabahat olarak cezalandırmaktadır. Şayet mağdur okul personeliyse fail birinci derece kabahatten sorumlu tutulur. Louisiana da siber zorbalığ ayrı bir suç olarak düzenlemeyi tercih eden eyaletler arasındadır. ${ }^{81} \mathrm{Her}$ türlü elektronik metin, görsel, yazı veya sözlü iletiyi zorlama, suiistimal, elem verme veya yıldırma amacıyla on sekiz yaşından küçük bir kişiye gönderen hakkında 500 dolara kadar para ve / veya altı aya kadar hapis cezasına hükmedilir.

faktörlerini dikkate alır.

3) Bu bölümdeki suçu işleyen kişi,

a. gerçek kişi ise, 2 yıla kadar hapis ve 50.000 dolara kadar adli para cezasıyla,

b. tüzel kişi ise, 200.000 dolara kadar adli para cezasıyla cezalandırılır.

4) Bu bölümde mağdur, bir dijital iletinin hedefi olan kişiyi ifade eder."

Düzenlemenin ilgili kısmı şu şekildedir;

Siber Zorbalık

"Bir kişi;

a. korkutma, zorlama, sindirme, tehdit, suistimal veya hakaret amacıyla bir başka kişiye, elektronik yolla bir ileti ulaştırır, gönderir veya yollarsa ve,

b. ileti diğer kişiye yönelik şiddetli, tekrarlanan veya düşmanca davranış şeklindeyse, siber zorbalıktan sorumlu olur." AR Code § 5-71-217 (2015). 


\section{SİBER ZORBALIĞIN MEVCUT SUÇ TIPPLERINNE GÖRE CEZALANDIRILMASI}

\section{Genel Olarak}

Bağımsız bir suç tipi oluşturmaya alternatif olarak, çeşitli yasalarda mevcut olan cezai hükümlere giderek siber zorbalığı cezalandırmak tercih edilen ikinci modeldir. Daha ziyade yüz yüze şekilde işlenen çeşitli suçlara, tipikliğinin gerçekleşmesi halinde siber zorbalığın cezaland1rılmasında başvurulabilir. Ayrıca kanun koyucular elektronik şekilde gerçekleştirilen bu tür eylemlerin cezalandırılabilmesini sağlamak amacıyla, mevcut suç tiplerine "telekomünikasyon veya elektronik araçlarla" işlenme gibi unsurlar ekleme yoluna gitmektedirler. ${ }^{82}$

\section{Karşılaştırmalı Hukuktaki Örnekler}

Siber zorbalık, Birleşik Krallık'ta ayrı bir suç tipi olarak düzenlenmemiş olmakla birlikte, failin mevzuatta dağınık şekilde bulunan çeşitli cezai hükümler çerçevesinde sorumluluğu doğabilir. Örneğin; Kamu Düzeni Kanunu (Puclic Order Act 1986) rahatsılık, korku veya elem yaratmaya elverişli şekilde tehdit, hakaret, aşağılama içeren söz, yazı veya herhangi bir görsele bir kişinin huzurunda başvurulmasını suç olarak düzenlemiştir. Konumuz bakımından esas olarak 2003 tarihli İletişim Kanunu'na (Communications Act 2003) bakılabilir. Anılan Kanun'un 127. bölümü elektronik iletişimin uygunsuz kullanımına yönelik çeşitli suç tiplerini düzenler. Herhangi bir elektronik iletişim ağını kullanarak ağır şekilde saldırgan, uygunsuz, müstehcen veya benzer içerikte mesaj ya da materyal gönderen kişi altı aya kadar hapis veya para cezasına çarptırılır. Yine bu bölüm altında, rahatsızlık, sıkıntı veya yersiz endişe yaratmak amacıyla, bir elektronik iletişim ağını kullanarak yanlış olduğu bilinen bir mesajın gönderilmesi aynı şekilde cezalandırılır.

Alman Ceza Kanunu'nda da siber zorbalığa ilişkin özel bir düzenleme mevcut değildir. Böyle bir suç tipinin Kanun'a eklenmesinin gerekli olup olmadığı öğretide tartışılmıştır. Bir görüşe göre; toplumun konuya ilişkin farkındalığının artması yeni bir suç tipi düzenlemek için yeterli bir gerekçe değildir ve mevcut suç tipleri bu sorunla mücadelede büyük ölçüde yeterlidir. ${ }^{83}$ Aksi yöndeki görüşe göre; siber zorbalığın Al-

\footnotetext{
82 BOSTANCI BOZBAYINDIR, s. 435.
}

83 PREUß, Tamina, “Erforderlichkeit der Kriminalisierung des Cybermobbings Sinnvolle Schließung einer Gesetzeslücke oder bloßes Symbolstrafrecht?", KriPoz, Heft: 2, 2019, s. 104; SCHIEMANN, Anja, “Strafbarkeit des Cybermobbings de lege lata und de lege ferenda", Die Kriminalpolizei, Nr. 4, 2019, s. 10. 
man Ceza Kanunu'nda ayrıca düzenlenmesi gerekliliği vardır. ${ }^{84}$ Söz konusu tartışma bir yana, tipikliğin gerçekleşmesi halinde Kanun'da düzenlenen hakaret (m. 185), kötüleme (m. 186), iftira (m. 187), konuşmanın gizliliğini ihlal (m. 201), resim çekmek suretiyle özel hayatın gizli alanını ihlal (m. 201a), 1srarlı takip (m. 238), tehdit (m. 241), şantaj (m. 253), cebir tasviri (m. 131) gibi suçlardan sorumluluk ortaya çıabilir. ${ }^{85}$ Nitekim bağımsız bir suçu gerekli görmeyen yazarlar, mevcut suç tiplerinin yeniden düzenlenmesinin yeterli olduğunu belirtmektedirler. ${ }^{86}$ Alman kanun koyucusu da siber zorbalık eylemlerine cevap vermek amaciyla Kanun'un 201a. maddesinde, resim çekmek suretiyle özel hayatın gizli alanının ihlal edilmesini de suç kapsamına almıştır. ${ }^{87}$

İsviçre Ceza Kanunu, siber zorbalığa ilişkin özel düzenleme içermez. Öğretide böyle bir düzenlemeye ihtiyaç bulunmadı̆̆ı, özellikle gençleri tehdit eden klasik siber zorbalık şekillerinin Kanun'da çeşitli hükümlerde suç olarak düzenlendiği ifade edilmiştir. ${ }^{88} \mathrm{Bu}$ bağlamda ilgilinin, İsviçre Ceza Kanunu'nda yer alan tehdit (m. 180), cebir (m. 181), hakaret (m. 173), iftira (m. 174), sövme (m. 177) gibi suçlardan sorumluluğuna gidilebilir. Yine eylemin içeriğine bağlı olarak cinsel suçların gündeme gelmesi de mümkündür.

\section{Siber Zorbalığın Türk Ceza Kanunu Açısından Değerlendirilmesi}

Siber zorbalık, 5237 sayılı Türk Ceza Kanunu'nda (TCK) bağımsız bir suç tipi olarak düzenlenmemiş olmakla birlikte, kimi hallerde çevrimiçi ortamda gerçekleştirilen bu tür saldırıların cezalandırılması söz konusu olabilir. Özellikle hakaret, tehdit, şantaj, kişilerin huzur ve sükunu bozma, cinsel taciz, özel hayatın gizliliğini ihlal, kişisel verilerin kaydedilmesi, verileri hukuka aykırı olarak verme veya ele geçirme gibi suç tiplerinin dikkate alınması gerekir. Ayrıca belirtelim ki kanun koyucu adı geçen suçların bir kısmında değişikliğe giderek, siber zorbalık kapsamındaki eylemlere uygulanabilecek yaptırımları artırma yoluna

CORNELIUS, Kai, "Plädoyer für einen Cybermobbing-Straftatbestand”, Zeitschrift für Rechtspolitik, Heft: 6, 2014, s. 167.

85 JÜLICHER, Tim, "Cybermobbing in der Schule", Neue Juristische Wochenschrift, Heft: 39, 2019, s. 2802; KATZER, s. 72, 73;

86 SCHIEMANN, s. 10.

87 MüKoStGB - GRAF, § 201a kn. 69.

88 BRUN, s. 111. 
gitmiştir. Özel hayata ve hayatın gizli alanına karşı suçlar için öngörülen cezalardaki değişiklikler özellikle dikkat çekmektedir. ${ }^{89}$ Bu başlik altında, öncelikli olarak değerlendirilmesi gerektiğini düşündüğümüz suç tiplerine temel hatlariyla yer verilecektir.

\section{a. Hakaret}

TCK m. 125 gereğince bir kimseye onur, şeref ve saygınlığını rencide edebilecek nitelikte somut bir fiil veya olgu isnat eden veya sövmek suretiyle bir kimsenin onur, şeref ve saygınlığına saldıran kişi hakaret suçundan sorumlu tutulur. Siber zorbalığın belki de en yaygın gerçekleştiriliş şekillerinden olan hakaret suçuyla kişilerin şerefinin korunması hedeflenmektedir. Baskın durumdaki düalist görüşe göre; hakaret suçuyla korunan şerefin normatif ve fiili iki yönü mevcuttur. ${ }^{90} \mathrm{Bu}$ suç tipiyle bir yandan kişinin kendisine karşı beslediği içsel şerefi, diğer yandan üçüncü kişilerin gözündeki dışsal şerefi koruma altına alınmaktadır. ${ }^{91}$ Konumuzu oluşturan siber zorbalığın da hem kişinin öz saygısına hem de toplum içindeki konumuna zarar verdiğine şüphe yoktur.

Pek çok siber zorbalık örneğinin, hakaret suçunun maddi unsurunu oluşturan fiil veya olgu isnadı ya da sövme yoluyla gerçekleştirildiği görülür. Siber zorbalığın yaygın şekillerinden birisi mağdur adına açılan sahte sosyal medya hesaplarında küçük düşürücü veya hakaret içeren paylaşımlarda bulunulmasıdır. Mağdurun aşağılayıcı içerikte montajlanmış fotoğraflarının yayılması buna örnektir. ${ }^{92}$ Esasen bu gibi durumlarda siber zorbanın cezai sorumluluğu ortaya çıkacağından sorun teşkil

89 Söz konusu değişikliğin yapıldı ̆̆ 6352 sayılı Kanun'un konuya ilişkin gerekçesi şu şekildedir: "5237 sayılı Türk Ceza Kanunu'nun 132 nci, 133 üncü ve 134 üncü maddelerinde, özel hayatın gizliliğinin ve haberleşme hürriyetinin ceza hukukunda korunmasına yönelik hükümlere yer verilmiştir. Bununla birlikte, söz konusu Kanunun bugüne kadarki uygulamasında, belirtilen hakların korunması bakımından öngörülen cezaların yeterli olmadığı yönünde uygulama sonuçları tespit edilmiştir. Söz konusu suçlarda daha etkin şekilde mücadele edilebilmesi bakımından öngörülen maddelerdeki suçların cezaları arttırılmıştır."

90 TEZCAN, Durmuş / ERDEM, Mustafa Ruhan / ÖNOK, R. Murat, Teorik ve Pratik Ceza Özel Hukuku, 18. B., Seçkin Yay., Ankara, 2020, s. 629; KOCA, Mahmut / ÜZÜLMEZ, İlhan, Türk Ceza Hukuku Özel Hükümler, 6. B., Adalet Yay., Ankara, 2019, s. 469; ÖZBEK, Veli Özer / DOĞAN, Koray / BACAKSIZ, Pınar, Türk Ceza Hukuku Özel Hükümler, 15. B., Seçkin Yay., Ankara, 2020, s. 505.

91 ÖNDER, Ayhan, Şahıslara ve Mala Karşı Cürümler ve Bilişim Alanında Suçlar, Filiz Kitabevi, İstanbul 1994, s. 222; BeckOK StGB - VALERIUS, § 185 kn. 2. 
eden bir nokta bulunmaz. ${ }^{93}$ Öyle ki somut olayda aleniyet unsuru mevcutsa TCK m. 125/4 gereğince ceza da artırılacaktır. Daha önce de bahsedildiği üzere siber zorbalığın kamuya açık nitelik taşıması sık görülen bir durum olduğundan pek çok olayda ceza artırımına gidilecektir.

Kanun koyucu, fiil veya olgu isnadının bir kimsenin onur, şeref ve saygınlığını rencide edebilecek nitelikte olmasını; sövmenin ise bir kimsenin onur, şeref ve saygınlığına saldırı oluşturmasını aramıştır. Bu nitelikte olmayan eylemler hakaret suçuna vücut vermez. Bir kimseye yöneltilen söz veya hareketlerin hakaret niteliğinde olup olmadığını belirlerken toplumda geçerli olan örf ve adetleri, eylemin gerçekleştiği koşulları dikkate almak gerekir. ${ }^{44}$ Dolayısıyla her ne kadar muhatabında rahatsızlık yaratsa da yakınma, eleştiri, ${ }^{95}$ beddua ${ }^{96}$ niteliğindeki sözler suç oluşturmaz. Belirtelim ki özellikle internet ortamında yapılan paylaşımları değerlendirirken eşiğin daha yüksekte tutulması gerektiği savunulmuştur..$^{97}$ Nitekim sanal dünyanın kendine has bir dil ve üslubunun bu-

"Facebook internet sitesinde katılan adına açılmış bulunan sayfalarda katılana yönelik çok sayıda hakaret içerikli ifadenin bulunmuş olması ve 12.04.2011 tarihli oturumda sanığın bu sayfalara giriş yaptı̆̆ını kabul etmiş bulunması karşısında; sanı̆̆ın, katılanlar ... ve ...'ya yönelik olarak ayrı ayr TCK.nun 244/2 ve katılan ...'ya yönelik TCK.nun 125/1 ve 2. maddelerinde düzenlenen suçları işlediği anlaşıldı̆̆ uyuşmayan gerekçelerle beraatine karar verilmesi..." Yar. 8. CD., 2013/11654 E., 2014/12272 K., 14.05.2014.

SOYASLAN, Doğan, Ceza Hukuku Özel Hükümler, 13. B., Yetkin Yay., Ankara, 2021, s. 307, 308; TEZCAN / ERDEM / ÖNOK, s. 636; KOCA / ÜZÜLMEZ, s. 475.

"Incelenen dosyada, sanı̆̆ın, haksız olarak kendisine balık çiftliği kurma ruhsatı vermeyen memurlarla ilgili soruşturma izni vermeyen kurul üyeleri hakkında yazdiğı dilekçede yer alan "Anayasa, Kanunlar, Yönetmelikler, yargı hukuk hak anlamayan kıyakçı gaspçı zihniyetli icraatçılar hesabım iyi biliyorlar ya sonrası bu bağlamda görevim ülkeme aileme, özürlülere, inançlarıma hizmet vermek doğrultusundan konuyu TC makamlarına arz ederim" biçimindeki sözlerle kamu görevlilerine görevleri nedeniyle hakaret ettiği kabul edilen olay-

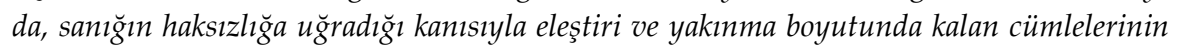
yukarıda açıklanan gerekçeyle hakaret suçunun öğelerini oluşturmadığı gözetilmeden yetersiz gerekçeyle mahkumiyet hükmü kurulması..." Yar. 4. CD., 2012/16551 E., 2014/2237 K., 28.01.2014.

96 "Sanığın, sulh ceza mahkemesinde yargılandĭ̆g davada karar açıklanırken tanık olarak dinlenen katılanlara söylediği "Şimdi bu polislere ellişer lira geçti değil mi, haram olsun" biçimindeki sözün, hakaret boyutuna ulaşmayan beddua niteliğinde olduğu ve hakaret suçunu oluşturmadığı gözetilmeden, beraat kararı verilmesi gerekirken kanuni olmayan gerekçe ile mahkumiyet kararı verilmesi..." Yar. 4. CD., 2013/268 E., 2014/5727 K., 24.02.2014. 
lunduğu unutulmamalıdır. İnternette iletişim kurarken nezaketin ön planda tutulmadığ 1 düşünüldüğünde, mahkemelerin daha esnek davranmasının gerekliliği anlaşılır. ${ }^{98} \mathrm{Bu}$ bağlamda, kullanılan ifadelerin mümkün olduğunca ağır eleştiri kapsamında değerlendirilmesi gerekir. Örneğin; Yargıtay benzer nitelikteki ifadeleri kimi zaman eleştiri kapsamında görmekte, kimi zamansa ilgilinin onur, şeref ve saygınlığını rencide etmeye yeterli saymaktadır. ${ }^{99} \mathrm{Bu}$ gibi olayların internet üzerinden tekrarlanarak gerçekleştirilmesi hallerinde dahi esnek olmak ceza hukukunun son çare olma özelliğine daha uygun düşer.

Görüldüğü üzere, hakaret suçu siber zorbalık şekillerinin belirli bir kısmını cezalandırabilir kılmaktadır. Hakaret oluşturmamakla birlikte yöneldiği kişide rahatsızlık yaratan kimi eylemlerin sürekli olarak, farklı vasıtalarla tekrarlanması olasıdır. Örneğin; kişiye sövme teşkil etmeyen lakaplar takmak ve bunu internette sıklıkla paylaşmak hakaret kapsamında değerlendirilemez. Şartlarının oluşması halinde kişilerin huzur ve sükunu bozma suçunu değerlendirmek mümkündür. ${ }^{100}$

\section{b. Kişilerin Huzur ve Sükunu Bozma}

TCK m. 123'e göre; sırf huzur ve sükûnunu bozmak maksadıyla bir kimseye ısrarla; telefon edilmesi, gürültü yapılması ya da aynı maksatla hukuka aykırı başka bir davranışta bulunulması durumunda kişilerin huzur ve sükununu bozma suçundan sorumluluk ortaya çıkar. Kanun koyucunun seçimlik olarak yer verdiği telefon etme, gürültü yapma ve hukuka aykırı başka bir davranışta bulunma hareketlerinden

98 DOERBECK, Caprice, Cybermobbing: Phänomenologische Betrachtung und strafrechtliche Analyse, Duncker \& Humblot, Berlin 2019, s. 146, 147.

99 Şu iki karar Yargıtay'ın çelişkili tutumuna örnek olarak gösterilebilir;

"Sanı̆̆ın, bir internet sitesinde yer alan ve katılanın onur, şeref ve saygınlığını rencide edecek mahiyetteki "cahil, yobaz" ifadeleri nedeniyle, hakaret suçunun oluştuğunun anlaşılması karşısında..." Yar. 4. CD., 2013/11461 E., 2014/8542 K., 20.03.2014.

"Inceleme konusu somut olayda; mahkemece, sanık ...'in katılan ....'e hitaben söylediği "gerici yobazlar" şeklindeki sözleri nedeniyle sanık hakkında hakaret suçundan mahkumiyet kararı verildiğinin anlaşılması karşısında; kaba söz ve ağır eleştiri niteliğindeki sözlerin, katılanın onur, şeref ve sayginlı̆̆ın rencide edici boyutta olmaması nedeniyle hakaret suçunun unsurlarının oluşmadığı anlaşıldı̆̆ından, sanığın hakaret suçundan beraati yerine mahkûmiyetine hükmedilmesinin, hukuka aykırı olduğu anlaşılmıştır." Yar. 18. CD., 2017/373 E., 2017/ 1182 K., 06.02.2017. 
birisinin ısrarlı şekilde yapılması gerekmektedir. O halde, hareketin yöneldiği kişi rahatsızlık duysa bile, tek bir kez gerçekleştirilen hareketler bu suçu oluşturmaz. ${ }^{101}$ Nitekim 1 srar unsuru siber zorbalık bakımından da genellikle karşımıza çıkan bir noktadır. Mağdura tekrar tekrar aynı mesajların gönderilmesi, sosyal medyadan çok sayıda paylaşım yapılması buna örnektir. Bunun yanında, bir kez gerçekleştirilen eylemlerin de siber zorbalık oluşturabileceği ifade edilmektedir. Nitekim mağduru komik durumda gösteren bir görselin internette paylaşılması tek bir hareket olmakla birlikte, farklı kişiler söz konusu görsele baktıkça tekrarlanan bir mağduriyet mevcuttur. Görüldügü üzere, kişilerin huzur ve sükununu bozma suçu her türlü siber zorbalık şeklini karşılayamamaktadir.

Israrlı şekilde gürültü yapılması siber zorbalık oluşturmamakla birlikte, diğer seçimlik hareketlerin devamlı icra edilmesi siber zorbalıkla örtüşebilir. Örneğin; mağdurun üçüncü bir kişiymiş gibi tekrar tekrar aranması halinde siber zorbalığın TCK m. 123 kapsamında cezaland1rılması mümkündür. Belirtelim ki uygulamada telefon etmek, kısa mesaj göndermeyi de içerecek şekilde yorumlanmaktadır. Yargıtay, birden fazla mesaj atılmasıyla da suçun işlenebileceğine hükmetmektedir. ${ }^{102}$ Dolayısıyla siber zorbalıkta sıklıkla karşımıza çıan mesaj atma şeklindeki hareketler ısrarlı şekilde gerçekleştirildiğinde cezalandırılabilir.

Kanun koyucu bir kişiye karşı hukuka aykırı başka davranışların 1srarla gerçekleştirilmesini de suç olarak düzenlenmiştir. Uygulamada ve öğretide, mağdurun araçla takip edilmesi, ${ }^{103}$ kapı zilinin farklı zaman-

101 ÖZBEK / DOĞAN / BACAKSIZ, s. 489; KOCASAKAL, Ümit, "Kişilerin Huzur ve Sükûnunu Bozma Suçu (TCK 123)”, Ankara Barosu Dergisi, C. 2, 2015, s. 134.

"Sanı̆̆ın, suç tarihinde, kendisini şikayet eden müştekiler D.. Ö.. ve G.. A..'ın kapılarını çalması, ancak açmamaları üzerine balkona çıkarak hakaret etmesi şeklinde gelişen olayda, TCK'nın 123. maddesindeki "süreklilik" unsuru gerçekleşmediği gibi "sırf huzur ve sükunu bozma" kastryla hareket ettiği sabit olmamasına karşın..." Yar. 4. CD., 2013/30598 E., 2014/32745 K., 12.11.2014.

"Sanığın katılanın telefonuna birden fazla mesajatarak gerçekleştirdiği eylemlerinin, TCK'nın 123. maddesinde düzenlenen kişilerin huzur ve sükununu bozma suçunun "ısrar" öğesini oluşturması karşısında.." Yar. 18. CD., 2015/12527 E., 2015/13772 K., 17.12.2015. Yargıtay'ın yorumunun kanunilik ilkesini zedelediği yönünde bkz. KOCASAKAL, s. 119. 
larda ve birden çok kez çalınması, ${ }^{104}$ önde giden aracın şoförünü rahatsız etmek amacıyla sürekli selektör yapılması ${ }^{105}$ bu kapsamda değerlendirilmiştir. Nitekim siber zorbalık kapsamında süreklilik arz eden kimi eylemler de bu kapsamda değerlendirilebilir. Örneğin; iletişim araçlarını devamlı kullanarak bir kimsenin rahatsız edilmesi siber zorbalık oluşturur ki böyle bir eylemin huzur ve sükunu bozma suçuna vücut vereceğine şüphe yoktur. Mağdura devamlı olarak şiddet içerikli resimler gönderilmesi, kavgaya kışkırtmaya yönelik provokatif e-postalar atılması cezalandırılabilir.

Siber zorbalığın süreklilik göstermesi gerekmediği gibi bu eylemlerin belirli bir saikle gerçekleştirilmesi de şart değildir. Gerçekten de eğlence gibi amaçlarla siber zorbalığa başvurulabileceği gibi hiçbir sebep olmaksızın zorbalık uygulanması da mümkündür. Halbuki kişilerin huzur ve sükununun bozulması suçu ancak özel kastla işlenebilir. ${ }^{106} \mathrm{Si}$ ber zorbalık ısrarlı şekilde gerçekleştirilse dahi özel kast ispat edilmediği sürece kişinin bu suçtan sorumluluğuna gidilemez.

\section{c. Tehdit}

Bir başkasını, kendisinin veya yakınının hayatına, vücut veya cinsel dokunulmazlığına yönelik bir saldırı gerçekleştireceğinden bahisle tehdit eden kişinin, TCK m. 106 gereğince cezai sorumluluğu ortaya çıkar. Suçun malvarlığı itibarıyla büyük bir zarara uğratacağından ya da sair bir kötülük yapacağından bahisle işlenmesi de mümkündür. Anlaşıldığ1 üzere kanun koyucu tehdidin yönelebileceği hukuki değerler bakımından bir sınırlamaya gitmemiş, suça konu bazı hukuki değerleri yapılacak kovuşturma ve verilecek ceza bakımından özellikle dikkate

haber vermek için eşinin iş yerine yöneldiği halde şüphelinin takibine devam ettiğini ve iş yerine girince şüphelinin de aracın park ettiği, durumu eşine anlatması ve eşinin isteği üzerine caddeye çıkıp yürüdüğ̈̈nde şüphelinin yeniden aracın çalıştırıp takibe geçtiği oluşa uygun olarak kabul edilmiş ve açıklanan eylemin kişilerin huzur ve sükununu bozma suçunu oluşturduğuna ilişkin vasıflandırmanın doğru olduğu anlaşıldığından..." Yar. 14. CD., 2012/8472 E., 2014/1008 K., 28.01.2014.

104 Yar. 4. CD., 2017/5261 E., 2018/1580 K., 25.01.2018.

105 ÖZBEK / DOĞAN / BACAKSIZ, s. 491.

"Sanı̆̆ın, katılanı birçok kez aradığım kabul ederek evlilikle ilgili konuştuklarını savunması, HTS kayıtlarından da konuşmaların uzun süreli olduğu ve şikayet tarihinden sonra da konuşmaların devam ettiğinin anlaşılması karşısında, samı̆̆ın "sırf huzur ve sükunu bozma" özel kastıyla hareket edip etmediği açılanmadan mahkumiyet kararı verilmesi..." Yar. 4. CD., 2013/34405 E., 2014/9725 K., 27.03.2014. 
almıştır. ${ }^{107}$ Hayata, vücut veya cinsel dokunulmazlığa yönelik yapılacağ1 belirtilen saldırının ağır olup olmamasının önemi yoktur. Öte yandan, malvarlığına yönelik gerçekleştirileceği söylenen saldırının büyük olması aranmıştır. Kanun koyucu saldırı tehdidinin yönelebileceği diğer hukuki değerler bakımındansa böyle bir ayrıma gitmemiştir. Bu bağlamda, kişinin şerefine, özel hayatına yöneltilen tehditler başkaca bir suçu oluşturmaması durumunda bu kapsamda değerlendirilir. ${ }^{108}$ En son andığımız bu değerlerin özellikle karşımıza çıkması olasıdır; zira siber zorbalık senaryolarında kişilerin onuruna, kişiliğine yönelik saldırı bildirimlerine sıklıkla başvurulur.

Siber zorbalığın somut olayın koşullarına göre tehdit suçunun unsurlarını oluşturması mümkündür. Elektronik iletişim araçlarını sıklıkla kullanarak mağduru rahatsız / tehdit etmek önemli bir siber zorbalık şeklidir ${ }^{109}$ ve TCK kapsamında cezalandırılabilir. ${ }^{110}$ Siber zorbalığın anonimlik özelliği, bu eylemlerin tehdit suçunu oluşturması halinde daha ağır şekilde cezalandırılmalarına da kapı açar. Nitekim TCK m. 106/2-c gereğince suçun, kişinin kendisini tanınmayacak bir hale koyması suretiyle, imzasız mektupla veya özel işaretlerle işlenmesi halinde cezada artırıma gidilir. Daha önce de vurgulandığı üzere, zorbalar sıklıkla sanal dünyanın sağladığı avantajdan faydalanarak gerçek kimliklerini saklamaktadırlar. Neticede tehdit suçunun unsurlarının oluşması halinde siber zorbalığın daha da ağır şekilde cezalandırılması olasıdır. Yine, yeni bir siber zorbalık şekli olduğu belirtilen "dolaylı tehdit"ler"111 de bu nitelikli hal kapsamında cezalandırılabilir. Zorbanın mağdurun göreceği bir internet sayfasına isimsiz şekilde tehdit mesajı yazması bu tür tehdidin klasik bir örneğidir.

Tehdit suçunun oluşması için tehdide konu hukuki değerin zarara sokulması gerekmez; zararın gerçekleştirilme olasılığının bulunması

\footnotetext{
107 TEZCAN / ERDEM / ÖNOK, s. 512, 513.

108 KOCA / ÜZÜLMEZ, s. 399.

BRENNER / REHBERG, s. 67.

110 “07/09/2010 tarihli tutanakla tespit edilen ve sanık tarafindan katılana gönderildiği anlaşılan, "harbiden ölümü hakediyorsun", "sana ömrüm boyunca varlı̆̆ımı hissettirecem, pişman olacaksın karşıma çıktı̆̆ına", " listemin en baş sırasındasın" şeklindeki mesajların tehdit suçunu oluşturduğu gözetilmeden, "her türlü şüpheden uzak delil elde edilemediği" biçimindeki yasal olmayan ve yerinde görülmeyen gerekçeyle sanı̆̆ın beraatine karar verilmesi..." Yar. 4. CD., 2013/2963 E., 2014/31770 K., 04.11.2014.
} 
yeterlidir. Belirtelim ki hukuki değere yönelen zarar bildiriminin belirli bir ağırlığa ulaşmış olması aranır. Öğretideki genel kanaate göre, tehdidin ciddiyetini belirlerken objektif bir ölçütten hareket edilmelidir. ${ }^{112}$ Dolayısıyla tehdidin mağdur üzerinde etkide bulunup bulunmadığına değil, ortalama bir kişinin bu bildirimi nasıl algılayacağına bakılmalıdır. Mağdur, failin yönelttiği tehditten etkilenmemiş olsa dahi suç oluşur. ${ }^{113}$ $\mathrm{Bu}$ durumun aksine, mağdurun objektif bakımdan elverişli olmayan zarar bildiriminden etkilenmesi suçun oluşmasını sonuçlamaz. Konumuz bakımından, objektif olarak muhatabını etkilemeye elverişli olmayan siber zorbalık fiillerinin gerçekleştirilmesi mümkündür ki bu eylemler tehdit kapsamında değerlendirilemez. Örneğin; mağdurun sanal dünyada dışlanması, yalnız bırakılması siber zorbalık şekillerinden bir tanesidir. Buna göre, zorba ya da zorbalar sistemli şekilde mağdurun sosyal medya hesaplarını kapattırabilir, bu hesapları verimli şekilde kullanmayı engelleyebilirler. Bu gibi durumlarda kişinin tüm hesaplarının kapattırılacağı, internette rahat verilmeyeceği gibi tehditlerde bulunulması objektif olarak mağduru etkilemeye elverişli olmadığından suçun oluşmayacağını düşünüyoruz.

\section{d. Cinsel Taciz}

TCK m. 105'te bir kişiyi cinsel amaçlı olarak taciz edenin cezalandırılacağı belirtilmektedir. Madde metninde hangi eylemlerin cinsel taciz kapsamına gireceği belirtilmemiştir. Kanun koyucu gerekçede, "cinsel taciz, kişinin vücut dokunulmazlı̆̆ının ihlali niteliği taşımayan cinsel davranışlarla gerçekleştirilebilir" ifadesini kullanmıştır. Dolayısıyla cinsel tacizi, cinsel saldırıdan farklı kılan nokta suçun vücut bütünlügünü ihlal etmeyen davranışlarla işlenmesidir. ${ }^{114} \mathrm{Bu}$ bağlamda, cinsel ilişki teklif etmek, cinsel organını göstermek, cinsel içerikli el kol hareketleri yapmak cinsel taciz suçuna vücut verir. ${ }^{115}$

112 TEZCAN / ERDEM / ÖNOK, s. 514; ÖZBEK / DOĞAN / BACAKSIZ, s. 406. Aksi yönde bkz. EREM, Faruk, Ümanist Doktrin Açısından Türk Ceza Hukuku, C. III, Özel Hükümler, 3. B., Seçkin Kitabevi, Ankara, 1985, s. 254.

113 SOYASLAN, s. 282; HEGHMANNS, Michael, Strafrecht für alle Semester - Besonderer Teil, Springer-Verlag, Berlin, 2009, s. 194.

114 TANER, Fahri Gökçen, Türk Ceza Hukukunda Cinsel Özgürlüğge Karşı Suçlar, 2. B., Seçkin Yay., Ankara 2017, s. 411.

115 YOKUŞ SEVÜK, Handan, Türk Ceza Hukuku Özel Hükümler, 2. B., Adalet Yay., Ankara, 2019, s. 183. 
Siber zorbalığın kimi durumlarda cinsel bir içerikle gerçekleştirilmesi söz konusudur. Bu gibi hallerde, vücut dokunulmazlığının ihlali de söz konusu olmadığından cinsel taciz suçunun değerlendirilmesi gerekir. Özellikle sexting olarak adlandırılan eylemler bu bağlamda değerlendirilebilir. Sexting öz bir ifadeyle, "cinsel anlam içeren görsellerin yayılması" olarak tanımlanabilir. ${ }^{116}$ Mağdura, çıplaklık içeren fotoğraf ya da videoların elektronik iletişim araçlarıyla gönderilmesi halinde sexting mevcuttur. Esasen bu gibi durumlarda eylemin daha ağır şekilde cezalandırılması söz konusudur; zira elektronik haberleşme araçlarının sağladığı kolaylıktan yararlanılması cezanın ağırlaştırılmasını gerektiren nitelikli hal olarak düzenlenmiştir. Kaldı ki elektronik ortamda gerçekleştirilen cinsel tacizin ispatı kimi hallerde kolaylık gösterebilir. Örneğin; e-posta veya SMS yoluyla cinsel tacizde bulunulduğunda fail geride iz birakmış olmaktadır.

Suçun ancak cinsel amaçlı davranışlarla işlenmesi mümkündür. Cinsel amaç gütmeyen, cinsel bir içeriği bulunmayan eylemler ısrarlı şekilde gerçekleştirilse dahi cinsel tacize vücut vermez. ${ }^{117} \mathrm{Bu}$ bağlamda arkadaşlık teklifinde bulunmak, yemeğe davet etme, çiçek göndermek gibi davranışlar cinsel taciz suçunu oluşturmaz. ${ }^{118}$ Anılan nitelikteki davranışların iletişim araçlarının kullanılarak gerçekleştirilmesi oldukça kolaydır. Süreklilik unsurunun bulunması halinde yukarıda tartışılan kişilerin huzur ve sükunu bozma suçundan ceza verilmesi söz konusu olabilir.

\section{e. Özel Hayata ve Hayatın Gizli Alanına Karşı Suçlar}

Siber zorbalık vakalarında, TCK'nın “Kişilere Karşı Suçlar” kısmının dokuzuncu bölümünde düzenlenen "Özel Hayata ve Hayatın Gizli Alanına Karşı Suçlar"ın birden fazlası karşımıza çıkabileceğinden, bu suçları aynı başlık altında incelemek istiyoruz. Özellikle fotoğraf, video, ses kaydı gibi materyallerin elektronik iletişim araçları yoluyla kolaylık-

\footnotetext{
116 BETTS, s. 20.

117 KOCA / ÜZÜLMEZ, s. 379; ÖZBEK / DOĞAN / BACAKSIZ, s. 395.

118 TEZCAN / ERDEM / ÖNOK, s. 489.

Yargıtay'ın aksi yönde kararları bulunmaktadır: "Sanığın ilgi duyduğu ve arkadaşlık yapmak istediği katılanı değişik zamanlarda telefon ile aramak, mesaj göndermek, mektup yazmak ve katılanın başka birisi ile evleneceğini bilmesine rağmen "Sevgililer Gününde" katılanın çalıştığı okula çiçek göndermekten ibaret eylemlerinin, TCK'nın 105/1. maddesine uyan cinsel taciz suçunu oluşturduğu gözetilmeden, kişilerin huzur ve sükununu bozma suçundan hüküm kurulması..." Yar. 18. CD., 2015/12132 E., 2016/1087 K., 20.01.2016.
} 
la yayılması mümkün olduğundan bu bölümde düzenlenen suç tipleri sıklıkla karşımıza çıkabilir. Yine kişisel bilgilerin, verilerin ele geçirilmesi ve internet ortamında yayılması olası bir senaryodur. Söz konusu vakalarda, gerçekleştirilen eylemlerin pek çoğunun TCK kapsamındaki çeşitli suçlara vücut verdiği görülebilir.

Kanun koyucu, TCK m. 132 vasıtasıyla haberleşmenin gizliliğini koruma altına almıştır. Haberleşme içeriklerinin hukuka aykırı olarak ifşa edilmesi siber zorbalığın görünüm şekillerinden bir tanesidir ${ }^{119}$ ve tipikliğin gerçekleşmesi halinde cezalandırılması mümkündür. Haberleşmenin gizliliğini ihlal suçu kapsamında korunan "haberleşme" bir vasıta aracılığıyla gerçekleştirilen iletişimi ifade eder. ${ }^{120}$ Nitekim günümüzde elektronik iletişim araçlar1 ${ }^{121}$ bireyler arası ilişkide en önemli unsurlardan birisini teşkil etmektedir. Kanun koyucu haberleşmenin gizliliğinin ihlalini tek başına cezalandırılabilir kılmış olsa da konumuz bakımından esas olan haberleşme içeriklerinin ifşasıdır. Öncelikle iki kişi arasında gerçekleştirilen haberleşme içeriklerinin fail tarafından hukuka aykırı olarak ifşa edilmesi söz konusu olabilir. Haberleşmenin taraflarından birisini ya da tamamını küçük düşürmeye yönelik bu eylemlerin siber zorbalık oluşturduğuna şüphe yoktur. Yine m. 132/3 kapsamında siber zorbanın kendisinin taraf olduğu haberleşme içeriklerini ifşa etmesi de suç oluşturmaktadır ki kanun koyucu bu ifşanın aleni olmasını aramıştır. Özellikle flaming ve outing olarak tabir edilen siber zorbalık hallerinde, alenen ifşanın bulunması şartıyla ilgilinin cezai sorumluluğuna gidilebilir. Bu hallerden ilkinde tartışma ortamı yaratıp mağduru kızdırmak için özellikle provokatif bir üslup kullanılmakta, mağdurla alay edilmektedir. Outing durumunda ise fail kendisinde kalacağı inancıyla paylaşılan kısa mesaj, e-posta gibi içerikleri ifşa etmektedir. Yine özellikle duygusal ilişkilerde intikam almak amacıyla yapılan haberleşme içeriklerinin ifşası da bu bağlamda karşımıza çıkabilir. ${ }^{122}$ Dolayısıyla

119 DÜLGER, s. 528.

120 ÖZBEK / DOĞAN / BACAKSIZ, s. 549.

1215809 sayılı Elektronik Haberleşme Kanunu m. 3/1-h'ye göre; “Elektronik haberleşme: elektriksel işaretlere dönüştürülebilen her türlü işaret, sembol, ses, görüntüve verinin kablo, telsiz, optik, elektrik, manyetik, elektromanyetik, elektrokimyasal, elektromekanik ve diğer iletim sistemleri vasıtasıla iletilmesini, gönderilmesini ve alınmasını" ifade eder.

122 "Dosya içeriğine ve sanı̆̆ın ikrara ilişkin beyanlarına göre, sanı̆̆ın, 8 yıl birliktelik yaşayarak yaklaşık 1 yıl önce ayrıldığı erkek arkadaşı olan katılan ile birliktelikleri döneminde yaptı̆̆̆ özel telefon konuşmalarını, rızasına aykırı olarak cep telefonu ile kayda alıp temyiz dışı sanık ...'in sahibi olduğu internet sitesinde yayımlatarak ifşa etmesi şeklinde gelişen eyle- 
bu şekilde gerçekleştirilen haberleşme içeriklerinin özellikle internet yoluyla yayılması ve mağdurun aşağılanması mümkündür.

Haberleşmenin gizliliğini ihlal suçu vasıta kullanmak suretiyle işlenebileceğinden, m. 133'te düzenlenen kişiler arasındaki konuşmaların dinlenmesi ve kayda alınması suçunun konusunu, araya bir vasıta girmeksizin yüz yüze gerçekleştirilen iletişim oluşturur. ${ }^{123}$ Siber zorbalığın ziyadesiyle iletişim araçları aracılığıyla gerçekleştirildiği düşünüldüğünde, 133. maddede düzenlenen bu suçun gerçekleşmesi daha zayıf bir ihtimaldir. Gerçekten de zorbalar genellikle e-posta içeriklerini, özel mesajlaşmaları yaymak gibi eylemlere başvurmaktadırlar. Ne var ki istisnai olarak, m. 133/3'te düzenlenen kayda alınan aleni olmayan konuşmaların ifşa edilmesi suretiyle siber zorbalıta bulunulması da mümkündür.

Siber zorbalık senaryolarının pek çoğunda mağdurun kişisel verilerinin ele geçirilmesi, üçüncü kişilere verilmesi ya da yayılması söz konusudur. En sık karşımıza çıkan, mağdur adına sahte sosyal medya hesabı açarak kişisel bilgileri paylaşmak gibi vakalar bunun en tipik örneğidir. Açllan sahte hesap üzerinden sanki mağdura aitmiş gibi paylaşımlar yapıldığı görülmektedir. Masquerading olarak adlandırılan bu tür siber zorbalıkta, yapılan paylaşımlar yoluyla mağdurun çevresindeki imajının sarsılmasına neden olunmaktadır. Normalde mağdurun yapmayacağ1 şekilde insanlara hakaret ederek, küçük düşürücü paylaşımlar yaparak insanlarla olan ilişkisinin bozulmasına yol açılır. Nitekim mağdurun verilerini ele geçirerek sahte hesap açmak, internette mağdurun kişisel bilgilerini yayacak şekilde eylemlerde bulunmak m. 136'da düzenlenen verileri hukuka aykırı olarak verme veya ele geçirme suçunu oluşturur. $^{124}$

minde; kendisiyle yapılan haberleşme içeriğini, diğger tarafın rızası olmaksızın belirli olmayan ve birden fazla kişi tarafından algılanabilme imkanı bulunan aleni bir ortamda ifşa eden sanı̆̆ın eyleminin, haberleşmenin gizliliğini ihlal suçunu oluşturduğundan..." Yar. 12. CD., 2013/26013 E., 2014/10209 K., 28.04.2014.

GÖKTÜRK, Neslihan, “Kişiler Arasındaki Konuşmaların Dinlenmesi ve Kayda Alınması Suçu (TCK m. 133)”, Türkiye Adalet Akademisi Dergisi, S. 24, 2016, s. 154.

"Oluşa ve dosya kapsamına göre; sanığın, daha önce mesai arkadaşı olan ve tek taraflı duygusal ilgi duyduğu katılanın isim, soyisim, elektronik posta adresi ve iş yeri bilgileri ile katılanın çalıştı̆̆g iş yerindeki resmi internet sayfasından elde ettiğ $\mathrm{i}$ katılana ait fotoğrafi kullanarak, evlilik sitesinde katılan adına profil düzenlediği, bu profili gören kişilerin katılana arkadaşlı isteği göndermesi üzerine katılanın durumdan haberdar olduğu olayda, katılan beyanı ve tüm dosya kapsamından sanığın üzerine atılı eylemin sabit olduğu anlaşıldığın- 
TCK m. 134'te düzenlenen özel hayatın gizliliğini ihlal suçu, Kanun'un bu bölümünde düzenlenen diğer suçlara göre genel norm niteliği taşır. ${ }^{125} \mathrm{O}$ halde, bu bölümde düzenlenmiş suç tiplerinden birisinin gerçekleşmesi halinde genel norm niteliğindeki özel hayatın gizliliğini ihlal suçu geri çekilir. Bu bölümdeki diğer maddelerin uygulanamadığı durumlarda siber zorbalık eylemlerinin de bu bağlamda cezalandırılması söz konusu olabilir. Özellikle happy slapping gibi siber zorbalık şekillerinin özel hayatın gizliliğini ihlal kapsamında cezalandırılması düşünülebilir. Bu siber zorbalık türünde, tanıklardan birisi video kaydı alırken saldırganın mağdura yaklaşıp tokatlaması / tartaklaması söz konusudur. Mağdurun bu şekilde küçük düşürüldüğü videolar internete yüklenmekte ve kısa sürede on binlerce insan tarafından izlenebilmektedir. Daha ziyade ergenler arasında gerçekleşen bu tür vakaların bir benzerini Yargıtay özel hayatın gizliliğini ihlal kapsamında değerlendirmiş, olayda şikâyet şartı gerçekleşmediğinden düşme kararı verilmesi gerektiğini belirlemiştir. ${ }^{126}$

dan, sanık hakkında, verileri hukuka aykırı olarak verme veya ele geçirme suçundan mahkumiyet kararı verilmesinde bir isabetsizlik görülmediğinden..." Yar. 12. CD., 2016/296 E., 2016/8375 K., 11.05.2016.

“Sanık ...'ın, mağdur .. ile resmi nikahlı eşi olan tanık ..'in birbirlerine gönderdikleri mesajları ve elektronik iletileri okuyup, her ikisi arasındaki duygusal yakınlaşmayı ve arkadaşlık ilişkisini öğrenmesi üzerine, mă̆dura tepki olarak, onun bilgisi ve rızası dışında, mağdurun adını ve soyadını taşıyan sahte facebook hesabı açı, mă̆durun günlük kıyafetleriyle poz vermiş şekilde çektirdiği bir resmini, bu hesapta yayımlaması şeklinde sübut bulan eyleminde, ad, soyad ve resim gibi mağdura ait kişisel verileri, hukuka uygunluk nedenlerinin bulunmaması nedeniyle hukuka aykırı olduğunda tereddüt bulunmayan bir yöntemle başkalarının görgüsüne sunmasından dolayı üzerine atılı TCK'nın 136/1. maddesinde tanımlanan verileri hukuka aykırı olarak verme veya ele geçirme suçunun yasal unsurlarının oluştuğu gözetilmeden" Yar. 12. CD., 2015/4006 E., 2015/18748 K., 02.12.2015. YOKUŞ SEVÜK, s. 265; KOCA / ÜZÜLMEZ, s. 550; GÖKTÜRK, s. 190.

126 “Suça sürüklenen çocuk ...'ın, mağdurun kavga anını cep telefonuna kaydetme eyleminin TCK'nın 134/1. maddesinin ikinci cümlesini, suça sürüklenen çocuk ...'in, bu görüntüleri internette yayımlama eyleminin ise aynı kanunun 134/2. maddesindeki suçları oluşturduğu, ancak suça sürüklenen çocuklara isnat edilen TCK'nın 134. Maddesindeki özel hayatın gizliliğini ihlal suçunun, ayn Kanun'un 139/1. maddesi uyarınca soruşturulması ve kovuşturulmasinın şikayete tabi olduğu, mağdurun 15 yaşından küçük olduğu, mağdurun kanuni temsilcisi olan annesi ...'in 09.05.2013 tarihli kolluk beyantnda kimseden davaci ve şikayetçi olmadı̆̆ımı beyan ettiği, sonraki aşamalarda şikayetçi olduğunu beyan eden katılan ...'in, şikayetten vazgeçmeden vazgeçmesinin mümkün olmadığı dikkate alındığında, suça sürüklenen çocukların müdafilerinin açıkça şikayetten vazgeçmeye karşı koymadı̆̆ı da nazara alınarak, şikayet koşulunun gerçekleşmemesi nedeniyle suça sürüklenen çocuklar hakkındaki davanın ayrı ayrı düşmesine karar verilmesi gerekirken, yargılamaya devamla yazılı 


\section{SİBER ZORBALIĞIN BAĞIMSIZ BİR SUÇ OLARAK DÜZENLENMESINIIN DEĞERLENDİRİLMESI}

Siber zorbalığa karşı ceza hukuku müdahalesinin gerekliliğine yönelik farklı görüşler ileri sürülmüştür. Nitekim bu fikirler doğrultusunda ceza hukukuna doğrudan başvurulduğu gibi yalnızca zararın tazmini seçeneğinin değerlendirildiği de gözlenebilir. ${ }^{127}$ Örneğin; hakaret ABD'nin pek çok eyaletinde suç değil haksız fiildir. Öte yandan, yalnızca tazminat hukukunun devreye sokulmasının ceza hukukundaki kadar etki yaratmasının mümkün olmadığı, her siber zorbalık formunda tazmin seçeneğinin kullanılamayacağı haklı olarak ifade edilmiştir. ${ }^{128} \mathrm{Her}$ ne kadar hakaret gibi eylemleri suç olmaktan çıkarma yönünde bir eğilim bulunsa da elektronik ortamda gerçekleştirilen hakaret, sövme fiillerinin ceza hukuku alanında tutulmaya devam edilmesinde fayda vardır. ${ }^{129}$ Siber zorbalık kapsamındaki davranışların gerçekleştirilmesi kolay olduğu kadar etkileri daha uzun süreli olabilmektedir. Örneğin; internette yayılan bir metin, video ya da ses kaydı derhal kaldırılamamakta, erişimin önü kesilene kadar belirli bir süre geçmektedir. Halihazırda pek çok devlet, siber zorbalığa karşı bir şekilde ceza hukuku müdahalesine başvurabilmektedir. Buraya kadar gösterildiği üzere, böyle bir müdahale yeni bir suç tipi yaratılması şeklinde olabileceği gibi mevcut ceza hukuku normlarından faydalanılması şeklinde de olabilir. Bu başlık altında öğretide savunulduğu gibi bağımsız bir suç tipine gerek bulunup bulunmadığı konusu tartışılacaktır.

Kişide rahatsızlık yaratan hemen her türlü söylemin, davranışın ceza hukuku alanına taşınması ifade özgürlüğüne ilişkin kaygıların doğmasına sebebiyet verir. Bu bağlamda siber zorbalığı ayrı bir suç olarak kaleme almanın, ifade özgürlüğünden faydalanmayı tehlikeye atabileceğine yönelik çekinceler dile getirilmektedir. ${ }^{130}$ Gerek bireylerin ge-

şekilde suça sürüklenen çocuklarm beraatine karar verilmesi..." Yar. 12. CD., 2014/16728 E., 2015/1677 K., 02.02.2015.

Hakaretin suç olmaktan çıkarılmasına yönelik eğilime yönelik karşılaştırmalı açıklamalar için bkz. KOCAOĞLU, Serhat Sinan, Uluslararası (AİHM) ve Ulusal Yargı İçtihatları Çerçevesinde Hakaret Suçu, Seçkin Yay., Ankara 2019, s. 447 vd.

SUMRALL, s. 1496, 1497.

Aynı yönde bkz. LIDSKY / GARCIA, s. 720.

SUMRALL, s. 1481; CAMPBELL, Marilyn / ZAVRSNIK, Ales, "Should Cyberbullying be Criminalized?", in Cyberbullying through the New Media: Findings from an International Network, Ed. SMITH, Peter K. / STEFFGEN, Georges, Psychology Press, Hove, 2013, s. 74. 
rekse toplumların gelişimi bakımından hayati önemi haiz olan bu hakkın korunmasında hassas davranılması elzemdir. Nitekim, yeni ve değişik fikirlerin ifade edilmesinin önü açıldığında hem kişilerin kültürel ve iletişimsel gelişimi sağlanır, hem de demokratik bir toplumun inşasına katılım mümkün olur. ${ }^{131}$ Yalnızca kabul edilebilir, benzer görüşlere değil, devleti veya toplumun bir kesimini rahatsız veya şoke edebilecek, saldırgan fikirlere de alan açılması gerekir. Ancak bu şekilde demokratik toplum için vazgeçilmez olan çoğulculuk, tolerans, açık fikirlilik gibi etmenler hayata geçirilebilir. ${ }^{132}$ İfade özgürlüğüne duyulan bu ihtiyaç, söz konusu hakkın sınırsız şekilde kullanılması anlamı taşımaz. İnsan Hakları Avrupa Mahkemesi (İHAM) de şiddete teşvik,,133 nefret söylemi, ${ }^{134}$ içeren ifadelerin koruma kapsamında olmadığının altını çizer. Türkiye bakımından değerlendirecek olursak, eleştiri niteliğindeki ifadelerin dahi hakaret suçu kapsamında değerlendirilebildiği görülmektedir. Örneğin; çirkef, ${ }^{135}$ lan ${ }^{136}$ gibi ifadeler onur, şeref ve saygınlığı rencide edecek nitelikte sayılmıştır. Dolayısıyla kuvvetli bir eleştiri kültürünün mevcut olmadığı Türkiye gibi ülkelerde, her türlü söylem ve eylemin kolaylıkla siber zorbalık kapsamında değerlendirilmesi tehlikesi mevcuttur.

Bilişim suçlarının en temel özelliklerinden birisi bu suçların genellikle uluslararası bir nitelik taşımasıdır. İnternetin sağladığı kolaylıklar sayesinde bilişim suçları rahatlıkla sınır aşan şekilde işlenebilir. Bilişim suçlarının her ülkede farklı şekillerde tanımlanması ise uluslararası iş

131 TEZCAN, Durmuş / ERDEM, Mustafa Ruhan / SANCAKDAR, Oğuz / ÖNOK, Rıfat Murat, İnsan Hakları El Kitabı, 8. B., Seçkin Yay., Ankara, 2019, s. 490, 492.

132 Handyside / Birleşik Krallık, Başvuru No: 5493/72, 07.12.1976, para. 49.

133 Sürek / Türkiye, Başvuru No: 26682/95, 08.07.1999, para. 62.

134 Vejdeland ve diğgerleri / İsveç, Başvuru No: 1813/07, 09.02.2012, para. 54, 55.

135 Yar. 18. CD., 2015/7206 E., 2015/11494 K., 18.11.2015.

136 "Olay günü karakola ait araçlar için tahsis edilmiş park yerine aractn park etmek istemesi nedeniyle çevre koruma nöbetçisi olan polis memuru müşteki ile tartışan ve tepkili biçimde aracını patinaj yaptırarak hızlı bir şekilde bulunduğu yerden alarak başka bir yere park edip geri gelen sanı̆̆ın, karakola girmek istediğinde kendisine nereye gideceğini soran müştekiye hitaben "sana ne lan, sen kimsin, ben istediğim yere gider, istediğim yerden çıkarım, bana kimse karışamaz" şeklinde sözler söylediŭi, sanı̆̆ın olumsuz tavrmı sözüyle pekişsirdiği, davranışlarmın bir bütün halinde görevini yapmakta olan müşteki polis memurunu tahkir etmek amaciyla ve müştekinin onur, şeref ve sayginlığın rencide edecek nitelikte olduğundan sözmek suretiyle işlenen, hakaret suçunun yasal unsurlarının oluştuğu kabul edilmelidir." Yar. CGK, 2014/756 E., 2015/124 K., 21.04.2015. 
birliğini oldukça zorlaştırır. ${ }^{137}$ Belirttiğimiz bu sorun, siber zorbalık durumunda da karşımıza çıkar. Örneğin; A ülkesindeki zorba, B ülkesinde yaşayan $C$ ülkesi vatandaşına $D$ ülkesindeki sunucu üzerinden siber zorbalıkta bulunabilir. Kimi hallerde suçun işlendiği ülkeler arasında iş birliği sözleşmesi bulunabilir, ancak böyle bir anlaşmanın mevcut olmadığı durumlarda ülkeler arasında koordinasyon sağlanması oldukça güçtür. Kaldı ki siber zorbalık kapsamında değerlendirilen çeşitli eylemler ulusal mevzuatlarda farklı şekillerde suç olarak kaleme alınmıştır. Aynı suç tipleri düzenleme altına alınmış olsa dahi maddi unsurlar bakımından önemli ayrımlar bulunabilir.

Öğretide ifade edilen çekincelerden bir tanesi de kanunilik ilkesine ilişkindir. ${ }^{138}$ Esasen kanunilik sorunu yukarıda bahsedilen uluslararası iş birliği konusuyla da yakından ilgilidir. Bilindiği üzere, kanuniliğin getirdiği en önemli güvencelerden bir tanesi de belirlilik ilkesidir. Buna göre, suç oluşturan davranışların ve bunların karşılığında öngörülen yaptırımların neler olduğunun açıkça belirtilmesi gerekir. Siber zorbalık örneğinde, anılan ilkeye uyum sağlanmasının önünde bir dizi sorun mevcuttur. Her şeyden önce, çalışmamızın girişinde bahsettiğimiz kavram sorunu karşımıza çıkar. Farklı ülkelerden akademisyenler sorunu değişik adlar altında değerlendirmektedirler. İngilizce konuşulan ülkelerde cyberbullying olarak adlandırılan siber zorbalık, Almanca kaynaklarda cyber-mobbing, İtalyanca kaynaklarda bullsimo virtual şeklinde anılmaktadır ki bu durum sorunun ilgili ülkenin kültüründeki belirli bir boyutunu dikkate alarak adlandırılmasından kaynaklanır. ${ }^{139}$ Her ne kadar bir suçun farklı ülkelerde değişik şekillerde adlandırılması normal bir durum olsa da bu adlandırmanın siber zorbalığı algılama şekillerinden de kaynaklandığını söylemek gerekir. Örneğin; mobbing ve bullying içerik olarak farklı davranışları karşılamakla birlikte siber zorbalığı tanımlarken kullanılmaktadırlar. ${ }^{140} \mathrm{Bu}$ durumun, siber zorbalığa ilişkin

\footnotetext{
137 DÜLGER, s. 189, 190; ERDOĞAN, s. 90, 91.

BOSTANCI BOZBAYINDIR, s. 442.

CAMPBELL / ZAVRSNIK, s. 74.

140 "Mobbing'in sözcük anlamı, psikolojik şiddet, baskı, kuşatma, taciz, rahatsız etme veya sıkıntı vermektir. Mobbing özellikle hiyerarşik bir yapılanmanın olduğu gruplarda, zayıf bir kontrolün olduğu örgütlerde güçlünün altta kalanlara psikolojik yollardan baskı yapmasıdır... Bullying bir kereden fazla tekrarlayan ve kasıtlı olarak başka birini yaralamak veya zarar vermek amacını taşıyan mağdur ve saldırganın güç eşitsizliğini içeren saldırgan davranıştır." GÜNŞEN İÇLİ, s. 157, 169.
} 
ortak bir paydada buluşulmasını zorlaştırdığını düşünüyoruz. Tüm bunların yanına aynı dil içerisinde dahi birlik sağlamak mümkün olmamaktadır. İngilizce kaynaklarda dahi internet zorbalığı, elektronik zorbalık gibi farklı ifadeler kullanıldığı görülmektedir.

Siber zorbalık çeşitlerinin içeriğini saptarken de belirlilik ilkesinin sağlanmasında güçlükler ortaya çıkabilir. Neticede siber zorbalık elektronik ortamda gerçekleştirilen bir dizi davranışı içeren bir çatı kavramdır. ${ }^{141}$ Hangi eylemlerin siber zorbalık oluşturduğuna ilişkin bir uzlaşı mevcut olmadığı gibi, bu eylemlerin içeriğine ilişkin de ortak bir nokta bulunmaz. Konuyu çalışan her yazar siber zorbalık oluşturan davranışları sayarken farklı listeler verir.

Siber zorbalığın bağımsız bir suç olarak düzenlenmesinin önleme bakımından olumlu bir etki yaratması kesin görünmemektedir. ABD'de yapılan bir araştırmaya göre; okullarda zorbalığı önlemeye yönelik düzenlemeler, zorbalık oluşturan eylemlerde yalnızca \% 8-12 oranında düşüş sağlamıştır. ${ }^{142}$ Dahası ceza tehdidi de zorbalığın azalmasında kayda değer bir etki ortaya koymamıştır. Aksine siber zorbalığın bağımsız bir suç tipi olarak düzenlenmesine rağmen bu tür eylemlerin artış gösterdiği gözlemlenebilmektedir. Örneğin; Yeni Zelanda'da siber zorbalığ1 cezalandırmaya yönelik pek çok kanun yürürlüğe sokulmuş olmakla birlikte, sanal ortamdaki zorba davranışlar artmaya devam etmiştir. $^{143}$

Belirttiğimiz sakıncalar da göz önünde bulundurulduğunda, siber zorbalığın ayrı bir suç olarak düzenlenmesinin gerekmediğini düşünüyoruz. Öncelikle, siber zorbalık kapsamındaki eylemlerin bir kısmının ceza hukukuna konu edilmesi hatalı olur. Ceza hukukunun ultima ratio olması gereği, her türlü yararın korunmasında ceza yaptırımına başvurulması düşünülemez. Örneğin; mağdurun, kasıtlı olarak yapılan aktivitelerin dışında bırakılmasını ifade eden dışlama (exclusion) siber zorbalık şeklinde de gerçekleştirilebilmektedir. ${ }^{144}$ Özellikle çocuklar ve ergenler arasında görülen, sosyal yaşamın bir getirisi olan bu tür olumsuzlukların çözümünde dahi ceza hukukuna başvurmak kabul edilemez. Ancak belirli yoğunluğa ulaşmış siber zorbalık şekillerinin cezalandırılması söz

\footnotetext{
141 BETTS, s. 9.

142 SABIA / BASS, s. 496.

143 FRANCO / GHANAYIM, s. 29.

144 BETTS, s. 19.
} 
konusu olabilir ki TCK'nın da bu konuda bir noktaya kadar yeterli olduğunu ifade etmek gerekir.

Siber zorbalık kapsamında görülen eylemlerin çoğu halihazırda TCK kapsamında suç olarak düzenlenmiş durumdadır. Hakaret, özel hayatın gizliliği gibi siber zorbalık türü olarak sıklıkla başvurulan fiiller nedeniyle ilgililerin cezai sorumluluklarına gidilmesi mümkündür. Öte yandan, gündelik hayatımızın çok büyük kısmını sanal dünyada geçirdiğimiz ve bu dünyanın suç işlemekte belirli avantajlar sağladığg düşünüldügünde, çeşitli nitelikli hallerin TCK'ya eklenmesi değerlendirilmelidir. Nitekim pek çok ülkede mevcut normların güncellenmesi yolunun tercih edildiği gözlemlenmektedir. ${ }^{145}$ Örneğin; cinsel tacizin posta veya elektronik haberleşme araçlarının sağladığı kolaylıktan faydalanmak suretiyle işlenmesi halinde verilecek ceza artırılmaktadır. Böyle bir nitelikli halin hakaret suçuyla, kişilerin huzur ve sükununu bozma suçlarına da eklenmesi düşünülmelidir.

Elektronik ortamda gerçekleştirilen zorbalıklar neticesinde özellikle gençler arasında intihar vakalarının yaşandığı bilinmektedir. Yine daha ziyade ergenler arasında gerçekleşen siber zorbalık neticesinde mağdurların okula gitmek istemedikleri ve hatta okulu bıraktıkları görülebilmektedir. Kimi zaman bununla da yetinilmeyip şehir değiştirildiği, yeni bir sayfa açmanın denendiği belirtilmiştir. İşte bu gibi ağır neticeleri de dikkate alacak şekilde belirli suç tiplerine neticesi sebebiyle ağırlaşmış hallerin eklenmesi gerekir. Nitekim benzer nitelikte bir yaklaşım belirli suç tiplerinde karşımıza çıkar. Örneğin; TCK m. 105'te düzenlenen cinsel taciz nedeniyle mağdur; işi bırakmak, okuldan veya ailesinden ayrılmak zorunda kalmış ise verilecek ceza bir yıldan az olamaz. Bu bağlamda, kişilerin huzur ve sükununu bozma, özel hayatın gizliliğini ihlal gibi eylemlerin mağdurun intihara yönelmesine, okulu veya işi bırakmasına yol açması neticesi sebebiyle ağırlaşmış hal olarak düzenlenebilir.

Siber zorbalık bahsinde ayrıca değinilmesi gereken konulardan birisi de 1srarlı takiptir. Esasen iki olgu birbirinden farklı olmakla birlikte,

145 Örneğin; Alman Ceza Kanunu'nun 201a. maddesinde düzenlenen "resim çekmek suretiyle özel hayatın gizli alanının ihlali" suçuna eklenen ikinci fıkrayla birlikte, kişinin itibarına önemli ölçüde zarar vermeye elverişli resminin üçüncü bir kişiye ifşa edilmesi suç olarak düzenlenmiştir. 
1srarlı takip (stalking)146 ve siber zorbalığın kesişmesi mümkündür. ${ }^{147}$ Gerçekten de siber 1srarlı takip (cyberstalking), 1srarlı takibin işleniş şekillerinden yalnızca birisidir ve siber zorbalık kapsamına girer. ${ }^{148}$ Özellikle kadına karşı şiddetle mücadele edilmesi bakımından ısrarlı takibin suç olarak düzenlenmesi gerektiği sıklıkla dile getirilmektedir. ${ }^{149}$ Esasen Türkiye'de kadına karşı şiddet olgusunun günden güne arttığı, ısrarlı takibin bu şiddetin önemli bir parçası olduğu düşünüldüğünde böyle bir düzenlemeye olan gereksinim daha net anlaşılabilir. Kanun koyucunun konuya ilişkin düzenlemeye gitmesi halinde, siber zorbalığın bir türü olan siber 1srarlı takibin de önünün kesilmesinde önemli bir adım atılmış olacaktır.

\section{SONUÇ}

İletişim tekniklerindeki ilerlemeye paralel olarak elektronik araçlar vasıtasıyla gerçekleştirilen saldırgan eylemler çeşitlenmiş ve çoğalmıştır. Öyle ki daha ziyade akranlar arasında görülen zorbalık eylemleri de elektronik bir kimliğe bürünerek mesafe ve zaman tanımaksızın mağdura uygulanabilir noktaya ulaşmıştır. İşte siber zorbalık olarak adlandırılan bu tür saldırganlık şeklinin özneleri de çeşitlidir ve her yaştan / profilden kişinin fail ya da mağdur olarak karşımıza çıkması mümkündür. Öğretmen, öğrenci arasında dahi siber zorbalık ilişkisinin ortaya çıkması mümkündür. Yine küçük bir çocuk bile kolaylıkla dünyanın öteki ucundaki ünlü ve zengin bir kişiye zorbalıkta bulunabilir. Siber zorbalığın bu derece kolaylıkla gerçekleştirilebilmesi ve intihar, okulu bırakma, işten

146 Kadına Yönelik Şiddet ve Aile İçi Şiddetin Önlenmesi ve Bunlarla Mücadeleye Dair Avrupa Konseyi Sözleşmesi (İstanbul Sözleşmesi) m. 34 gereğince, "Taraflar başka bir ş̧ahsa yö̈elik olarak gerçekleștirilen ve bu șahsl, șahsin kendisini gü̈ende hissetmesini ö̈leyecek şekilde korkutacak, kasıtlı bir biçimde tekrarlanan tehditkâr davranışların cezalandırılmasını temin edecek gerekli yasal veya digĕr tedbirleri alacaklardır."

6284 sayılı Ailenin Korunması ve Kadına Karşı Şiddetin Önlenmesine Dair Kanuna İlişkin Uygulama Yönetmeliği m. 3-ş'de "tek taraflı 1srarlı takip" şeklinde adland1rılan kavram; "Aralarında aile bă̆ı veya ilişki bulunup bulunmadığına bakılmaksızın, şiddet uygulayanın, şiddet mağduruna yönelik olarak, güvenliğinden endişe edecek şekilde fiziki veya psikolojik açıdan korku ve çaresizlik duygularına sebep olacak biçimde, içeriği ne olursa olsun fiili, sözlü, yazılı olarak ya da her türlü iletişim aracın kullanarak ve baskı altında tutacak her türlü tutum ve davranış" olarak tanımlanmıştır.

SCHIEMANN, s. 9.

148 Aynı yönde bkz. SOYGÜT, s. 188.

TANER, s. 422; SOYGÜT, s. 203, 204; DOĞAN, Recep, “Kadına Yönelik Şiddetin Bir Türü Olarak, Israrlı Takip (Stalking) Kavramı ve Suçu”, Ankara Barosu Dergisi, S. 2, 2014, s. 153. 
ayrılma gibi ağır neticelere yol açması hukuk müdahalesinin gerekliliğine ilişkin tartışmaları ateşlemiştir.

Siber zorbalık konusunda her ülkede farklı yaklaşım benimsendiğini söylemek hatalı olmaz. Özellikle ABD gibi ifade özgürlüğüne daha geniş alan tanınan ülkelerde siber zorbalığın cezalandırılması anlayışının hâkim olduğunu söylemek mümkün değildir. Tazminat hukukunun yanında, okulda gerçekleştirilen zorbalıklar açısından disiplin tedbirlerine başvurulduğu gözlemlenir. Kara Avrupası ülkelerinden siber zorbalığı cezalandırmaya yönelik yaklaşım baskındır. Ancak, bu ülkelerde de genel kanaat, ceza kanunlarındaki düzenlemelere başvurulmasının yeterli olacağı yönündedir. Nitekim Türkiye, Almanya gibi ülkelerde hakaret, özel hayatın gizliliğini ihlal gibi suç tiplerine siber zorbalığın cezalandırılmasında başvurulabilir. Avusturya örneğindeki gibi istisnai hallerde siber zorbalık bağımsız bir suç tipi olarak kaleme alınabilmektedir.

Türkiye özelinde değerlendirmede bulunursak, siber zorbalığa ayrı bir suç olarak yer verilmesinin gerekmediği, TCK'da yapılacak bazı değişikliklerin ve eklemelerin yeterli olacağı söylenebilir. Kaldı ki böyle bir girişimde bulunmak da pratik güçlüklere gebedir. Kavramın içeriğinin muğlaklığı kanunilik ilkesinin sağlanmasını zorlaştırır. Yine siber zorbalığın sınır aşan boyuta sahip olması da ceza muhakemesi bakımından faile ulaşılması, delillerin elde edilmesi gibi güçlükler yaratır. Bu bağlamda, belirli suç tiplerine cezayı ağırlatıcı nitelikli haller ve neticesi sebebiyle ağırlaşmış haller eklemek faydalı olacaktır. Özellikle hakaret suçuyla kişilerin huzur ve sükununu bozma suçlarının elektronik iletişim araçları vasıtasıyla işlenmeleri halinde verilecek ceza artırılmalıdır. Son olarak, hakaret, özel hayatın gizliliğini ihlal gibi suçların alenen işlenmesi mağdurun işini veya okulunu bırakmasına ve hatta intiharına neden olabileceğinden neticesi sebebiyle ağırlaşmış hal düzenlenmesi düşünülmelidir. 


\section{KAYNAKLAR}

AKBULUT, Berrin, Bilişim Alanında Suçlar, 2. B., Adalet Yay., Ankara 2017.

ARICAK, Tolga / SIYAHHAN, Sinem / UZUNHASANOGLU, Aysegul / SARIBEYOGLU, Sevda / CIPLAK, Songul / YILMAZ, Nesrin / MEMMEDOV, Cemil, "Cyberbullying among Turkish Adolescents", CyberPsychology \& Behavior, Vol. 11, Iss. 3, 2008, s. 253261.

AUER-REINSDORFF, Astrid, "Kinderschutz im Internet: Technische Lösungen sowie Informationsangebote an Eltern, Schulen und Kinder", Familie Partnerschaft Recht, Heft: 10, 2012, s. 434-437.

Beck'scher Online Kommentar - StGB, 49. Aufl., C. H. Beck, München 2021. (BeckOK StGB)

BARUTÇU YILDIRIM, Funda, "Siber Zorbalığın Sonuçları", in Siber Zorbalık, Ed. TANRIKULU, İbrahim, Anı Yay., Ankara 2020, s. 210-222.

BETTS, Lucy R., Cyberbullying: Approaches, Consequences and Interventions, s. Palgrave Macmillan, Nottingham, 2016.

BOSTANCI BOZBAYINDIR, Gülşah, "Cyberbullying and Criminal Law", İstanbul Hukuk Mecmuası, S. 77, C. 1, 2019, s. 425-450.

BRENNER, Susan W. / REHBERG, Megan, “'Kiddie Crime'? The Utility of Criminal Law in Controlling Cyberbullying", First Amendment Law Review, Vol. 8, 2009, s. 1-85.

BRUN, Marcel, “Cyberbullying - aus strafrechtlicher Sicht", Recht, Heft: 2, 2016, s. 100-111.

CAMPBELL, Marilyn / ZAVRSNIK, Ales, "Should Cyberbullying be Criminalized?", in Cyberbullying through the New Media: Findings from an International Network, Ed. SMITH, Peter K. / STEFFGEN, Georges, Psychology Press, Hove, 2013, s. 65-82.

CHISHOLM, June F., "Review of the Status of Cyberbullying and Cyberbullying Prevention", Journal of Information Systems Education, Vol. 25, Iss. 1, 2014, s. 77-87.

CORNELIUS, Kai, "Plädoyer für einen Cybermobbing-Straftatbestand", Zeitschrift für Rechtspolitik, Heft: 6, 2014, s. 164-167. 
DEHUE, Francine / BOLMAN, Catherine / VÖLLINK, Trijntje, "Cyberbullying: Youngsters' Experiences and Parental Perception", CyberPsychology \& Behavior, Vol. 11, Iss. 2, 2008, s. 217-223.

DİLMAÇ, Bülent / AYDOĞAN, Didem, "Parental Attitudes as a Predictor of Cyber Bullying among Primary School Children", International Scholarly and Scientific Research \& Innovation, Vol. 4, Iss. 7, 2010, s. 1667-1671.

DOERBECK, Caprice, Cybermobbing: Phänomenologische Betrachtung und strafrechtliche Analyse, Duncker \& Humblot, Berlin 2019.

DOĞAN, Recep, “Kadına Yönelik Şiddetin Bir Türü Olarak, Israrlı Takip (Stalking) Kavramı ve Suçu", Ankara Barosu Dergisi, S. 2, 2014, s. 135-154.

DOOLEY, Julian J. / PYZALSKI, Jacek / CROSS, Donna, “Cyberbullying Versus Face-to-Face Bullying: A Theoretical and Conceptual Review", Zeitschrift für Psychologie / Journal of Psychology, Vol. 217, Iss. 4, 2009, s. 182-188.

DÜLGER, Murat Volkan: Bilişim Suçları ve İnternet İletişim Hukuku, 8. B., Seçkin Yay., Ankara, 2020.

ERDOĞAN, Yavuz, Türk Ceza Kanunu'nda Bilişim Suçları, Legal Yay., İstanbul 2013.

EREM, Faruk, Ümanist Doktrin Açısından Türk Ceza Hukuku, C. III, Özel Hükümler, 3. B., Seçkin Kitabevi, Ankara, 1985.

EROĞLU, Yüksel / GÜLER, Neşe, “Koşullu Öz-Değer, Riskli İnternet Davranışları ve Siber Zorbalık / Mağduriyet Arasındaki İlişkinin İncelenmesi", Sakarya University Journal of Education, C. 5, S. 3, 2015, s. 118-129.

FIRAT, Meryem / AYRAN, Gülsün, “Üniversite Öğrencileri Arasında Sanal Zorbalık", TAF Preventive Medicine Bulletin, C. 15, S. 4, 2016, s. 322-329.

FRANCO, Liat / GHANAYIM, Khalid, "The Criminalization of Cyberbullying Among Children and Youth", Santa Clara Journal of International Law, Vol. 17, Iss. 2, 2019, s. 1-49.

GÖKTÜRK, Neslihan, "Kişiler Arasındaki Konuşmaların Dinlenmesi ve Kayda Alınması Suçu (TCK m. 133)", Türkiye Adalet Akademisi Dergisi, S. 24, 2016, s. 149-198. 
GÖLPEK SARI, Fatma / SEFEROĞLU, Süleyman Sadi, “Ortaokul Öğrencilerinin Sanal Zorbalık Farkındalık Durumları ile Sanal Zorbalık Yapma ve Mağdur Olma Durumlarının İncelenmesi", Online Journal of Technology Addiction and Cyberbullying, C. 6, S. 1, 2019, s. 54-77.

GÜNŞEN İÇLİ, Tülin, Kriminoloji, 10. B., Seçkin Yay., Ankara 2019.

HEGHMANNS, Michael, Strafrecht für alle Semester - Besonderer Teil, Springer-Verlag, Berlin, 2009.

JOECKS, Wolfgang / MIEBACH, Klaus, Münchener Kommentar zum StGB, Band 4, 3. Aufl., Verlag C. H. Beck, München, 2017.

JÜLICHER, Tim, “Cybermobbing in der Schule", Neue Juristische Wochenschrift, Heft: 39, 2019, s. 2801-2805.

KATZER, Catarina, Cybermobbing - Wenn das Internet zur Waffe wird, Springer-Verlag, Berlin, 2014.

KOCA, Mahmut / ÜZÜLMEZ, İlhan, Türk Ceza Hukuku Özel Hükümler, 6. B., Adalet Yay., Ankara 2019.

KOCAOĞLU, Serhat Sinan, Uluslararası (AİHM) ve Ulusal Yarg1 İçtihatları Çerçevesinde Hakaret Suçu, Seçkin Yay., Ankara 2019.

KOCASAKAL, Ümit, “Kişilerin Huzur ve Sükûnunu Bozma Suçu (TCK 123)", Ankara Barosu Dergisi, C. 2, 2015, s. 109-146.

KOWALSKI, Robin M. / LIMBER, Susan P., “Electronic Bullying Among Middle School Students", Journal of Adolescent Health, Vol. 41, 2007, s. 22-30.

KOWALSKI, Robin M. / LIMBER, Susan P. / AGATSTON, Patricia W., Cyberbullying: Bullying in the Digital Age, Wiley-Blackwell, Malden, 2012.

KYRIACOU, Chris / ZUIN, Antônio, “Cyberbullying of Teachers by Students on Youtube: Challenging the Image of Teacher Authority in the Digital Age", Research Papers in Education, Vol. 31, Iss. 3, 2016, s. 255-273.

LANGOS, Colette, Cyberbullying, Associated Harm and the Criminal Law, University of South Australia 2013 (Yayımlanmamış doktora tezi). 
LIDSKY, Lyrissa / GARCIA, Andrea Pinzon, "How Not to Criminalize Cyberbullying", Missouri Law Review, Vol. 77, Iss. 3, 2012, s. 693-726.

MARK, Lauren / RATLIFFE, Katherine T., “Cyber Worlds: New Playgrounds for Bullying", Computers in School, Vol. 28, Iss. 2, 2011, s. 92-116.

NIXON, Charisse L., "Current Perspectives: The Impact of Cyberbullying on Adolescent Health", Adolescent Health, Medicine and Therapeutics, Vol. 5, 2014, s. 143-158.

ORTEGA, Rosario / ELIPE, Paz / MORA-MERCHAN, Joaquin A. / GENTA, M. Luisa / BRIGHI, Antonella / GUARINI, Annalisa / SMITH, Peter K. / THOMPSON, Fran / TIPPETT, Neil, “The Emotional Impact of Bullying and Cyberbullying on Victims: A European Cross-National Study", Aggressive Behavior, Vol. 38, 2012, s. 342-356.

ÖNDER, Ayhan, Şahıslara ve Mala Karşı Cürümler ve Bilişim Alanında Suçlar, Filiz Kitabevi, İstanbul 1994.

ÖZBEK, Veli Özer / DOĞAN, Koray / BACAKSIZ, Pınar, Türk Ceza Hukuku Özel Hükümler, 15. B., Seçkin Yay., Ankara, 2020.

PATCHIN, Justin W. / HINDUJA, Sameer, "Bullies Move Beyond the Schoolyard: A Preliminary Look at Cyberbullying", Youth Violence and Juvenile Justice, Vol. 4, Iss. 2, 2006, s. 148-169.

POLAT, Oğuz, Kriminoloji ve Kriminalistik Üzerine Notlar, 4. B., Seçkin Yay., Ankara 2018.

PREUß, Tamina, “Erforderlichkeit der Kriminalisierung des Cybermobbings - Sinnvolle Schließung einer Gesetzeslücke oder bloßes Symbolstrafrecht?", KriPoz, Heft: 2, 2019, s. 97-104.

PYZALSKI, Jacek, "From Cyberbullying to Electronic Aggression: Typology of the Phenomenon", Emotional and Behavioural Difficulties, Vol. 17, No. 3-4, 2012, s. 305-317.

RIZZA, Caroline / PEREIRA, Angela Guimaraes, Social Networks and Cyber-bullying among Teenagers, Publications Office of the EU, Luxembourg, 2013. 
RODKIN, Philip C. / FISCHER, Karla, “Cyberbullying from Psychological and Legal Perspectives", Missouri Law Review, Vol. 77, Iss. 3, 2012, s. 619-640.

RTÜK, Çocukların Yeni Medya Kullanım Alışkanlıkları ve Siber Zorbalık, Değişim Yay., Ankara 2018.

SABIA, Joseph J. / BASS, Brittany, “Do Anti-Bullying Laws Work? New Evidence on School Safety and Youth Violence", Journal of Population Economics, Vol. 30, 2017, s. 473-502.

SAVAGE, Matthew W. / TOKUNAGA, Robert S., "Moving toward a Theory: Testing an Integrated Model of Cyberbullying Perpetration, Aggression, Social Skills, and Internet Self-efficacy", Computers in Human Behavior, Vol. 71, 2017, s. 353-361.

SCHENK, Allison M. / FREMOUW, William J., "Prevalence, Psychological Impact, and Coping of Cyberbully Victims Among College Students", Journal of School Violence, Vol. 11, 2012, s. 21-37.

SCHIEMANN, Anja, "Strafbarkeit des Cybermobbings de lege lata und de lege ferenda", Die Kriminalpolizei, Nr. 4, 2019, s. 7-10.

SOYASLAN, Doğan, Ceza Hukuku Özel Hükümler, 13. B., Yetkin Yay., Ankara, 2021.

SOYGÜT, M. Buket, “Kadına Yönelik Dijital Şiddet Biçimi Olarak SiberStalking", in Kadın Yazıları, Ed. YALÇIN, Türkan, Savaş Yay., Ankara 2020, s. 177-211.

SÖZÜER, Eren, Unutulma Hakkı, On İki Levha Yay., İstanbul 2017. SUMRALL, Tiffany, "Lethal Words: The Harmful Impact of Cyberbullying and the Need for Federal Criminalization", Houston Law Review, Vol. 53, Iss. 5, 2016, s. 1475-1501.

TANER, Fahri Gökçen, Türk Ceza Hukukunda Cinsel Özgürlüğe Karşı Suçlar, 2. B., Seçkin Yay., Ankara 2017.

TANRIKULU, İbrahim, "Siber Zorbalık ve Kavramsal Konular", in Siber Zorbalık, Ed. TANRIKULU, İbrahim, Anı Yay., Ankara 2020, s. 7-22.

TAŞTEKİN, Ezgi / BAYHAN, Pınar, “Ergenler Arasındaki Siber Zorbalığın ve Mağduriyetin İncelenmesi", Online Journal of Technology Addiction and Cyberbullying, C. 5, S. 2, 2018, s. 21-45. 
TEZCAN, Durmuş / ERDEM, Mustafa Ruhan / ÖNOK, R. Murat, Teorik ve Pratik Ceza Özel Hukuku, 18. B., Seçkin Yay., Ankara, 2020.

TEZCAN, Durmuş / ERDEM, Mustafa Ruhan / SANCAKDAR, Oğuz / ÖNOK, Rıfat Murat, İnsan Hakları El Kitabı, 8. B., Seçkin Yay., Ankara, 2019.

THOMAS, Hannah J. / CONNOR, Jason P. / SCOTT, James G., “Integrating Traditional Bullying and Cyberbullying: Challenges of Definition and Measurement in Adolescents - a Review", Educational Psychology Review, Vol. 27, Iss. 1, 2015, s. 135-152.

TOKUNAGA, Robert S., "Following You Home from School: A Critical Review and Synthesis of Research on Cyberbullying Victimization", Computers in Human Behavior, Vol. 26, 2010, s. 277-287.

UŞAKLIOĞLU, Ahmet Yavuz, Dijital Hukuk, 2. B., Seçkin Yay., Ankara 2021.

VANDEBOSCH, Heidi / CLEEMPUT, Katrien Van, “Defining Cyberbullying: A Qualitative Research into the Perceptions of Youngsters", CyberPsychology \& Behavior, Vol. 11, Iss. 4, 2008, s. 499-503.

VOGL-BAUER, Sally, “When Disgruntled Students Go to Extremes: The Cyberbullying of Instructors", Communication Education, Vol. 63, Iss. 4, 2014, s. 429-448.

YOKUŞ SEVÜK, Handan, Türk Ceza Hukuku Özel Hükümler, 2. B., Adalet Yay., Ankara, 2019.

WILLIAMS, Kirk R. / GUERRA, Nancy G., “Prevalence and Predictors of Internet Bullying", Journal of Adolescent Health, Vol. 41, 2007, s. 14-21.

\section{İNTERNET KAYNAKLARI}

StopBullying, "What is Cyberbullying?", www.stopbullying.gov/cyberbullying/what-is-it.

UNICEF, "Cyberbullying: What Is It and How to Stop It?", www.unicef.org/end-violence/how-to-stop-cyberbullying. 